\title{
Perceived Effects of Bush Burning on Agriculture and Wildlife Resources in Ghana
}

\author{
Caitlin A. Wilson \\ West Virginia University, cw0032@mix.wvu.edu
}

Follow this and additional works at: https://researchrepository.wvu.edu/etd

Part of the Agriculture Commons, and the Food Security Commons

\section{Recommended Citation}

Wilson, Caitlin A., "Perceived Effects of Bush Burning on Agriculture and Wildlife Resources in Ghana" (2020). Graduate Theses, Dissertations, and Problem Reports. 7829.

https://researchrepository.wvu.edu/etd/7829

This Thesis is protected by copyright and/or related rights. It has been brought to you by the The Research Repository @ WVU with permission from the rights-holder(s). You are free to use this Thesis in any way that is permitted by the copyright and related rights legislation that applies to your use. For other uses you must obtain permission from the rights-holder(s) directly, unless additional rights are indicated by a Creative Commons license in the record and/ or on the work itself. This Thesis has been accepted for inclusion in WVU Graduate Theses, Dissertations, and Problem Reports collection by an authorized administrator of The Research Repository @ WVU. For more information, please contact researchrepository@mail.wvu.edu. 
Perceived Effects of Bush Burning on Agricultural and Wildlife Resources in Ghana

\title{
Caitlin Wilson
}

\begin{abstract}
Thesis submitted to the Davis College of Agriculture, Natural Resources, and Design at West Virginia University

In partial fulfillment of the requirements for the degree of Master of Science in Wildlife and Fisheries Resources
\end{abstract}

James T. Anderson, Ph.D., Chair

Donald J. Brown, Ph. D.

Steven Selin, Ph.D.

Division of Forestry and Natural Resources

Morgantown, West Virginia

2020

Keywords: bush burning, Ghana, agriculture, wildlife, behavior

Copyright 2020 Caitlin Wilson 


\begin{abstract}
Perceived Effects of Bush Burning on Agriculture and Wildlife Resources in Ghana
\end{abstract}

\title{
Caitlin Wilson
}

Peace Corps was started in the 1960s by President John F. Kennedy. Ghana was one of the first established host countries that received Peace Corps Volunteers. There are five different sectors that volunteers can work in education, health, agriculture, environment, or community and economic development. Peace Corps service begins with ten weeks of pre-service training before volunteers swear in and are placed in communities throughout the country. Training covers topics such as global Peace Corps policy, health and security concerns, local language, and technical skills. I was placed in a small, rural community in the Northern Region of Ghana. My projects focused on food security, such as growing orange flesh sweet potatoes and building a community garden. Peace Corps service came with many challenges, but the relationships I built with my community and my cohort were invaluable.

As part of my service and my graduate studies, I interviewed farmers in northern Ghana about their perceptions of the effect of bush burning on agriculture and wildlife in the area. Fires are a key aspect of savanna ecology, but current anthropogenic uses of bush burning are causing soil degradation and a decrease in food security in northern Ghana. We interviewed 87 farmers on their bush burning behavior to determine if demographic factors influenced the reasoning behind farmers bush burning practices. Interviews took place in ten communities across the Northern Region using Barrier Analysis Surveys. Results were both quantitative and qualitative. Data analysis was conducted using logistic regression modeling. The number of participants categorized as burners or non-burners were modeled using demographic information and participants' perceptions of the effects of bush burning. Models were selected based on $\triangle \mathrm{AICc}$ and weight. We were able to determine some of the motivations people had to practice or not practice bush burning. Motivations to avoid bush burning included the perceived severity of its effects on agriculture and wildlife, the perceived lack of effectiveness, perceived negative consequences, and access to tools and materials. Motivations to use bush burning included perceived effectiveness and perceived positive consequences. We were also able to determine participants' perceptions of the effects of bush burning on their farms and for wildlife. Participants noted a variety of negative consequences such as impacts to crop yield, income, soil fertility, and erosion as well as some positive consequences such as benefits to seed germination and ease of use to clear land for farming. Participants also provided some strategies to discourage the use of bush burning. Providing better access to conservation agriculture education and punishing those caught bush burning could discourage people from and therefore potentially increase their household's income and food security. 


\section{Acknowledgments}

I thank my advisor, Dr. James Anderson, and the rest of my graduate committee, Dr. Brown and Dr. Selin, for their support. I also thank Dr. Ida Holaskova and Matthew Walker for their statistics expertise. I am grateful to my Peace Corps cohort and friends as well as my counterpart and the staff of Peace Corps Ghana. I also thank my friends and family in the United States who supported me throughout my service in Ghana. 


\section{Table of Contents}

ACKNOWLEDGMENTS

LIST OF TABLES $\quad$ V

LIST OF FIGURES

$\begin{array}{ll}\text { Abstract } & 2\end{array}$

Ghana for Twenty-Seven Months

$\begin{array}{lr}\text { Literature Cited } & 18\end{array}$

$\begin{array}{ll}\text { Introduction } & 22\end{array}$

Materials and Methods $\quad 25$

$\begin{array}{ll}\text { Results } & 27\end{array}$

$\begin{array}{ll}\text { Discussion } & 30\end{array}$

$\begin{array}{ll}\text { Figures } & 44\end{array}$

Appendix I: Barrier Analysis Survey- the questions asked each participant during the survey. 51 


\section{List of Tables}

\section{Chapter Two}

Table The ten communities of the Northern Region, Ghana that, in 2019, participated in the barrier analysis study of bush burning, as well as their respective district, and approximate population as of the time of the survey. Surveys (n $=87$ ) were conducted through an interview process with farmers in each community that volunteered to participate

Table 2 The question number, question and coded response for each open-ended research question used in the barrier analysis surveys in 10 participating communities in the Northern Region, Ghana, 2019. Surveys $(\mathrm{n}=87)$ were conducted through an interview process with farmers in each community that volunteered to participate. Responses from the open-ended questions were coded based on overall themes present

Table 3 Model selection results for research question 3 (Agriculture Perceptions), research question 4 (Wildlife Perceptions, and research question 10 (Religious Perceptions) from the barrier analysis surveys. Surveys were conducted in 10 communities in the Northern Region of Ghana in 2019. Surveys $(n=87)$ were conducted through an interview process with farmers in each community that volunteered to participate. Predictor variables for the models were years of farming experience, age of participants, district, participants' perceptions of the effects of bush burning on agriculture and wildlife, and if they thought God approved or disapproved of bush burning. The response variables were how participants were classified as burners or non-burners based on their response to the barrier analysis screening question and depending on whether the research question pertained to agriculture, hunting, or both. Models with $\triangle \mathrm{AICc}$ values $<2$ are good candidate models. We selected the model with the lowest $\Delta \mathrm{AICc}$ that was also contained the most variables. * indicates selected model for parameter estimation

Table 4 The parameter estimate, standard error, and 85\% confidence interval for each individual predictor from the selected models. Models were selected based on AICc, $\triangle \mathrm{AICc}$, and weight. Data for the models were taken from a barrier analysis study conducted in 10 communities in the Northern Region of Ghana in 2019. Surveys $(n=87)$ were conducted through an interview process with farmers in each community that volunteered to participate. Predictor variables for the models were years of farming experience, age of participants, district, participants' perceptions of the effects of bush burning on agriculture and wildlife, and if they thought God approved or disapproved of bush burning. The response variables were how participants were classified as burners or non-burners based on their response to the barrier analysis screening question and depending on whether the research question pertained to 
agriculture, hunting, or both. In JMP Pro 15 the parameter estimates for Negative/Positive Effects on Farm were based off of yes (there are negative effects) responses which were coded as 1. In JMP Pro 15 the parameter estimates for God Approves/Disapproves were based off of approved responses which were coded as 1

Table 5 The number and percentage of participant responses to research question 19 (What actions, interventions, or strategies do you think would be effective in encouraging people to stop bush burning?). Surveys $(n=87)$ were conducted through an interview process with farmers, in each community, that volunteered to participate. Participant responses were coded based on overall themes between the responses. Percentages are listed in each coded category from the barrier analysis survey conducted in 10 communities in the Northern Region of Ghana in 2019 


\section{List of Figures}

\section{Chapter One}

Fig 1 Map depicting where Ghana is located on the African continent as well as where the Kukurantumi Training Office and the training community of Anyinasin were located within Ghana

Fig 2 The front of my house in Kpataribogu, the community I lived in 2018 and 2019. Kpataribogu is in Karaga District in the Northern Region of Ghana

Fig 3 Waakye, a Ghanaian dish made with rice and beans. Photo credit Maha Patrick

Fig 4 Two examples of batik fabric which are be found in markets across West Africa

Fig 5 Two examples of wax print fabric, which are be found in markets across West Africa

Fig 6 Two examples of kente cloth, which is traditionally made in Northern Ghana

Fig 7 My cohort in Anyinasin, Ghana after the Swearing-In Ceremony on 14 December 2017. I am in the middle of the third row, with the bright blue top

Fig 8 My counterpart and some of the women's group using hoes to dig ridges and mounds for sweet potatoes, July 2018, Kpataribogu, Northern Region

Fig 9 The women planting sweet potato vines, July 2018, Kpataribogu, Northern Region

Fig 10 Approximately 2100kg of sweet potato tubers that were harvested by the women's group, November 2019, Kpataribogu, Northern Region

Fig 11 My counterpart teaching Peace Corps volunteers and their counterparts about orange flesh sweet potatoes at a training in Pishigu, Northern Region in July 2019

Fig 12 Musah using a piece of rope to show volunteers and counterparts the correct way to plant sweet potato vines, July 2019, Pishigu, Northern Region

Fig 13 My counterpart, his son, and a friend planting sweet potato vines in the dry season garden, November 2019, Kpataribogu, Northern Region

Fig 14 My cohort at our close of service conference on Volta Lake, Ghana in September 2019. Photo and Logo Credit: Kurt Uhlendorf

\section{Chapter Two}

Fig 1 Map depicting the location of Ghana on the African continent and the 10 participating communities from the Northern Region that were surveyed $(\mathrm{n}=87)$ during this study, 2019 
Fig 2 The number of participants by their years of farming experience, in groupings of five years, from the 10 participating communities in the Northern Region, Ghana, 2019. Surveys $(n=87)$ were conducted through an interview process with farmers in each community that volunteered to participate

Fig 3 The overall percentage of participants from the 10 participating communities in the Northern Region, Ghana who used bush burning for farming, hunting, farming and hunting, or not at all. Participants were categorized into each category based on their responses to the screening question section of the barrier analysis survey conducted in 2019. Surveys $(n=87)$ were conducted through an interview process with farmers in each community that volunteered to participate

Fig 4 The probability of a participant, from one of the 10 participating communities in the Northern Region, Ghana, being categorized as a non-burner for farming. Probability was calculated from the most parsimonious model using years of farming experience and whether a participant thought that bush burning had a negative effect on their farm from research question 3 . The confidence interval for the No response to research question 3 is not depicted due to the small sample size of participants that answered no. Surveys $(n=87)$ were conducted in 2019 through an interview process with farmers in each community that volunteered to participate

Fig 5 The probability of a participant, from one of the 10 participating communities in the Northern Region, Ghana, being categorized as a non-burner for hunting. Probability is calculated from the most parsimonious model, using age of the participants. Surveys $(n=87)$ were conducted in 2019 through an interview process with farmers in each community that volunteered to participate

Fig 6 The probability of a participant, from one of the 10 participating communities in the Northern Region, Ghana, being categorized as a non-burner for either hunting or farming. Probability is calculated from the most parsimonious model using years of farming experience and whether a participant thought that God approved or disapproved of bush burning from research question 10. The confidence interval for the Approve response to research question 10 is not depicted due to the small sample size of participants who responded that God approved. Surveys $(n=87)$ were conducted in 2019 through an interview process with farmers in each community that volunteered to participate 
Fig 7 The number of participants and the species they hunted from the 10 communities in the Northern Region, Ghana that participated in the barrier analysis survey conducted in 2019. Surveys $(n=87)$ were conducted through an interview process with farmers in each community that volunteered to participate 


\title{
Chapter 1
}

\section{Experiences in Peace Corps Ghana}

\author{
Caitlin Wilson, M. S. ${ }^{1}$
}

${ }^{1}$ West Virginia University

Davis College of Agriculture, Natural Resources and Design

Division of Forestry and Natural Resources

Morgantown, West Virginia, USA 


\begin{abstract}
Peace Corps was started in the 1960s by President John F. Kennedy. Ghana was one of the first established host countries that received Peace Corps Volunteers. There are five different sectors that volunteers can work in, including education, health, agriculture, environment, or community and economic development. Peace Corps service begins with ten weeks of pre-service training before volunteers swear in and are placed in communities throughout the country. Training covers topics such as global Peace Corps policy, health and security concerns, local language, and technical skills. I was placed in a small, rural community in the Northern Region of Ghana. My projects focused on food security, such as growing orange flesh sweet potatoes and building a community garden. Peace Corps service came with many challenges, but the relationships I built with my community and my cohort were invaluable.
\end{abstract}




\section{Ghana for Twenty-Seven Months}

\section{Peace Corps History and Overview of Peace Corps Ghana}

Peace Corps was established on 1 March 1961 by an executive order by President John F. Kennedy (JFK Library 2020). This executive order was the culmination of Kennedy's efforts to involve Americans in world democracy, peace, and development. R. Sargent Shriver, Kennedy's brother-in-law was named the first Peace Corps Director (JFK Library 2020). The first countries to welcome Peace Corps Volunteers were Tanganyika, now called Tanzania, and Ghana. From 1961 to 1981, Peace Corps operated as part of the U.S. State Department but was made an independent organization in 1981. The organization has three goals: 1) to help the people of interested countries and areas in meeting their needs for trained workers; 2) to help promote a better understanding of Americans on the part of people served; 3 ) to help promote a better understanding of other people on the part of Americans (Peace Corps 2020a),

During the 1960s, the organization focused on education and agriculture and recruited recent college graduates (Peace Corps 2020a). However, after the Vietnam War the number of volunteers declined due to a distrust in the government (Peace Corps 2020a). In the 1980s President Ronald Reagan expanded the organization's focus to include computer and business literacy programs in order to draw in more volunteers (Peace Corps 2020a). Currently, Peace Corps operates in more than 60 countries and has more than 7,000 volunteers in six different sectors: agriculture, community economic development, education, environment, health, and youth in development (Peace Corps 2020a). For Peace Corps to operate in a country, the country must invite Peace Corps and propose different target areas where the most help is needed (Peace Corps 2020a).

Peace Corps Ghana has operated continuously since 1961, when it was opened as one of the inaugural Peace Corps countries (Peace Corps 2020b). Ghanaian President Dr. Kwame Nkrumah received the first 52 volunteers on 30 August 1961. Since then about 4,800 Peace Corps volunteers have served in every region of Ghana. Currently the country hosts about 117 health, education and agriculture volunteers (Peace Corps 2020b). In Ghana, volunteers learn various languages including Twi, Ewe, Dagaare, Dagbani, Mampruli, Gurune, and Ghanaian Sign Language. Volunteers in Ghana live in a diverse set of living conditions. Peace Corps volunteers can be found in both urban and rural areas and can live with a host family or independently (Peace Corps 2020b). 


\section{Pre-Service Training}

Every volunteer's Peace Corps experience begins with ten weeks of pre-service training (Peace Corps 2020c). Pre-service training is organized by in-country staff and current volunteers. In-country staff usually consist of host country nationals that are hired for their expertise. Pre-service training covers five different topics: technical, language, health, safety and security, and cross-cultural experiences. Peace Corps trainees are assessed on their competency in these five different areas before they can swear in as volunteers. During the technical training portion of pre-service training, trainees learn the technical knowledge they need to be successful in their communities (Peace Corps 2020c). For example, agriculture volunteers learn country-specific agriculture knowledge, while health volunteers learn about relevant health issues. Language training is conducted in small groups and Peace Corps trainees learn the local language that their placement community speaks. Health training covers all the various health issues that a volunteer may expect to encounter during service (Peace Corps 2020c). The safety and security portion addresses how to manage potential security issues, so that volunteers will feel safe in their host country. Finally, cross-cultural training provides information on different aspects of the host country culture and how a volunteer's behavior can be perceived (Peace Corps 2020c).

Pre-service Training in Ghana took place in Anyinasin near the Peace Corps training center in Kukurantumi, Eastern Region from 3 October to 14 December 2017 (Figure 1). During my pre-service training, days were split between language and technical training. We usually spent six hours a day in language training and the other two focusing on technical training. This was the schedule for every day of the week except Thursday and Sunday. On Thursdays we traveled to the training center in Kukurantumi to have sessions on health, safety and security, and cross-cultural information. We covered a variety of topics including common health issues, tips for safety and security, global Peace Corps policies, and information about Ghanaian culture. Sundays were our only day off during the week and were usually spent doing laundry and spending time with our host families. 


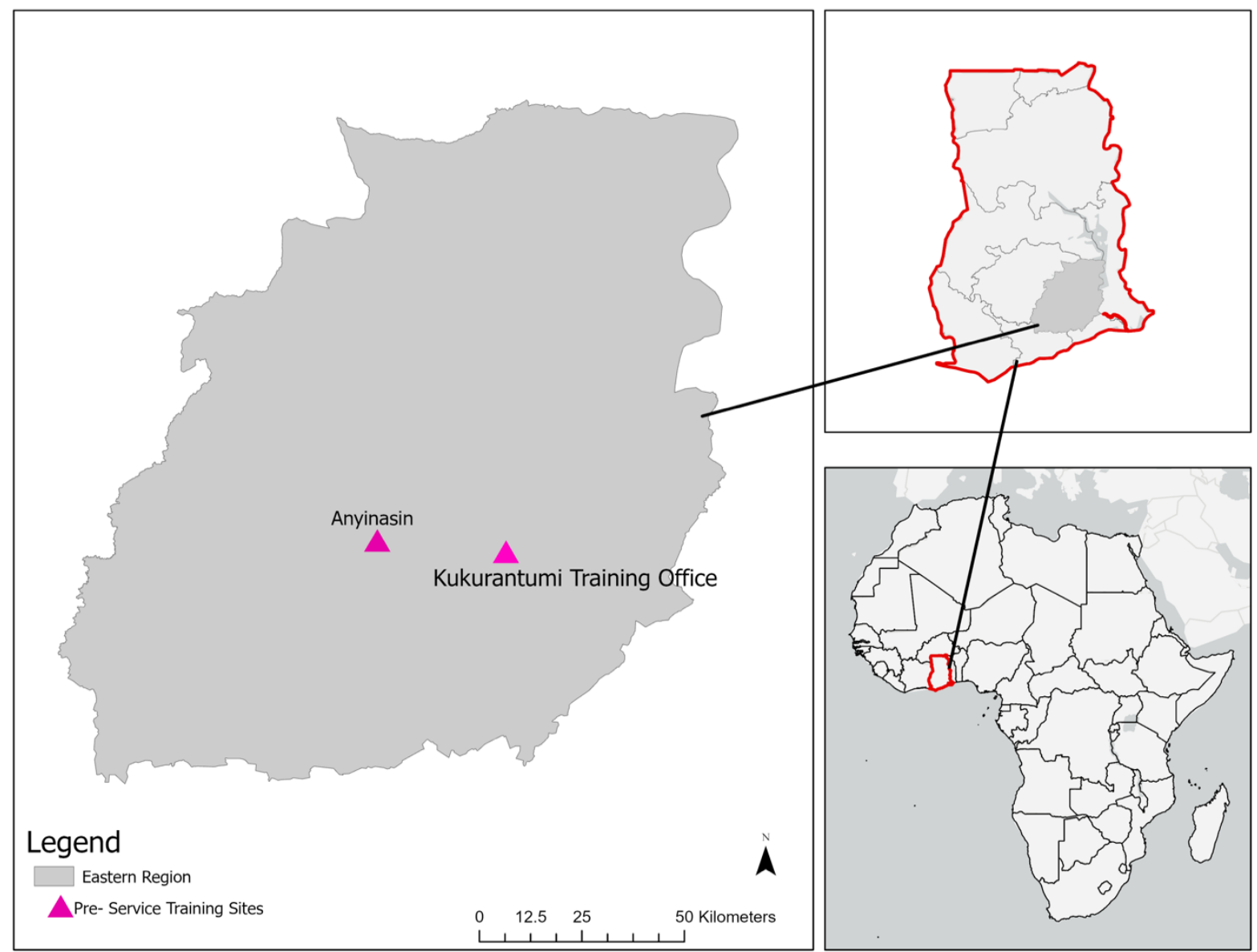

Fig 1 Map depicting where Ghana is located on the African continent as well as where the Kukurantumi Training Office and the training community of Anyinasin were located within Ghana

For language training we were split into groups based on the language being taught. There were two Dagaare and two Twi groups as well as one for Dagbani, one Mampruli, one Likpakpaln, and one Gurune. I was taught Dagbani along with two other trainees. Our language sessions covered everything from greetings to food to agricultural terminology. For technical training we came together as one group to have both lecture and practical sessions on agriculture in Ghana. We learned about climate smart agriculture, perma-gardens, commonly grown crops, common pests, as well as shea (Vitellaria paradoxa) and cashew (Anacardium occidentale) products. During week eight, we traveled to visit our communities and to see where we would be living and to start meeting the people we would be working with. My community was Kpataribogu, which was in Karaga District, in the Northern Region (Figure 2). It was about $84 \mathrm{~km}$ northeast of Tamale, the regional capital. After about four days in our 
communities, we traveled to Dalun, Northern Region for off-site technical training. This was a ten-day period, where we focused on agriculture topics for most of the day, with two hours spent on language training.

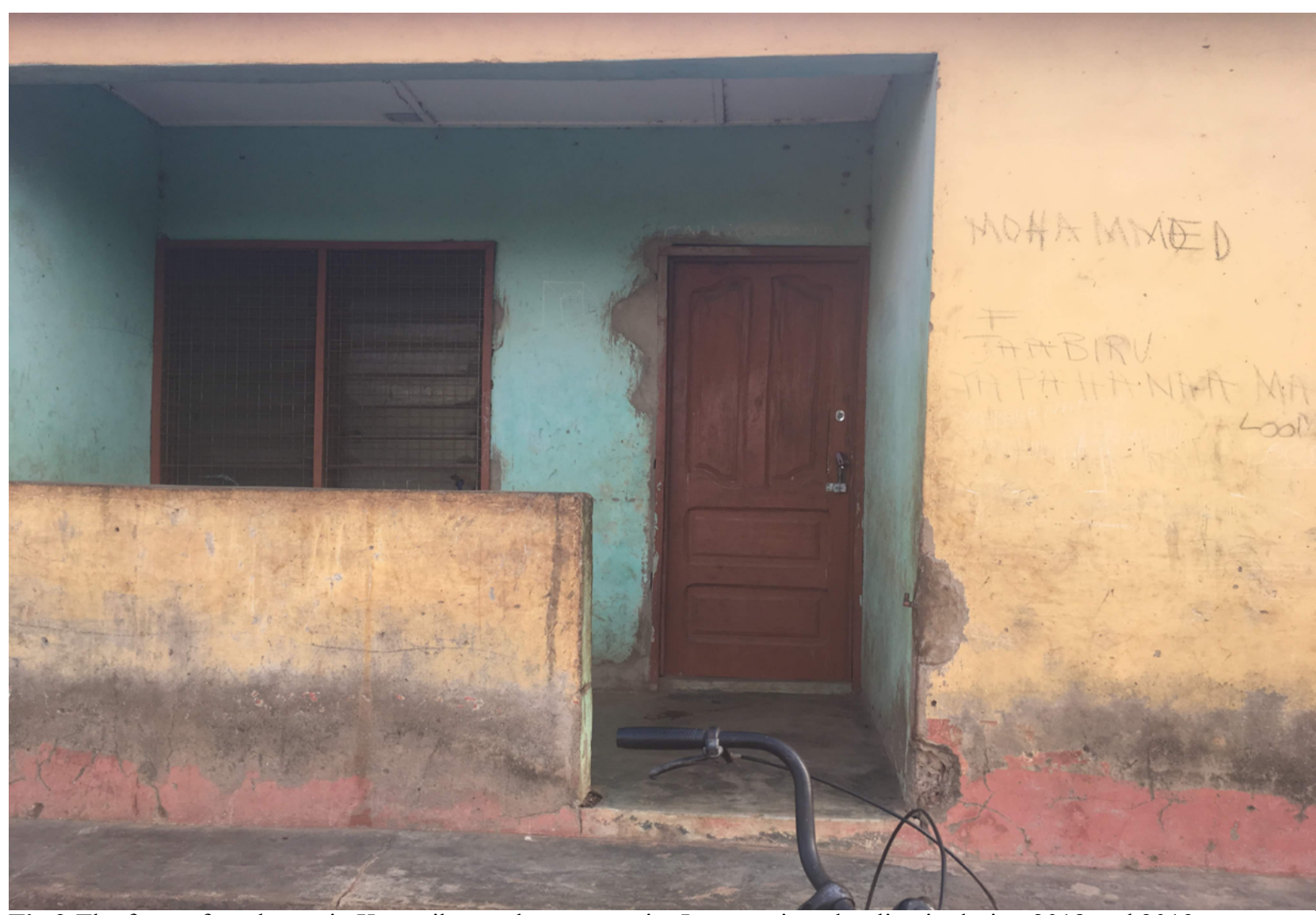

Fig 2 The front of my house in Kpataribogu, the community I was assigned to live in during 2018 and 2019. Kpataribogu is in Karaga District in the Northern Region of Ghana

Following off-site training we traveled back to Eastern Region to complete the last two weeks of training.

These last two weeks were busy, and we were required to complete two projects which were evaluated. The first one was the Small Community Outreach Project and the second was the Personal Project Presentation. We worked in small groups for both projects. The Small Community Outreach Project involved planning and facilitating a twohour session on a selected agriculture topic. My group chose to do a nutritional cooking demonstration with women from the community. The women were all host mothers for trainees from my cohort. We cooked waakye, a local rice and bean dish, while discussing different ways to make it more nutritious (Figure 3). We discussed using onethird rice (Oryza sativa) to two-thirds beans (Vigna unguiculate unguiculate) to have a complete source of protein, meaning that every amino acid was present in the food. We also discussed adding vegetables, like tomatoes (Solanum lycopersicum), garden egg (Solanum macrocarpon), bell peppers (Capsicum annuum), and carrots (Daucus carota sativus), to provide additional nutrients. While the Small Community Outreach Project tested our 
technical knowledge, the Personal Project Presentation evaluated our cultural understanding. Each group was required to focus on a topic that highlighted an aspect of Ghanaian culture. My group chose to focus on different fabrics and how they used the cloth as well as exhibited examples of each (Figure 4, 5, 6).

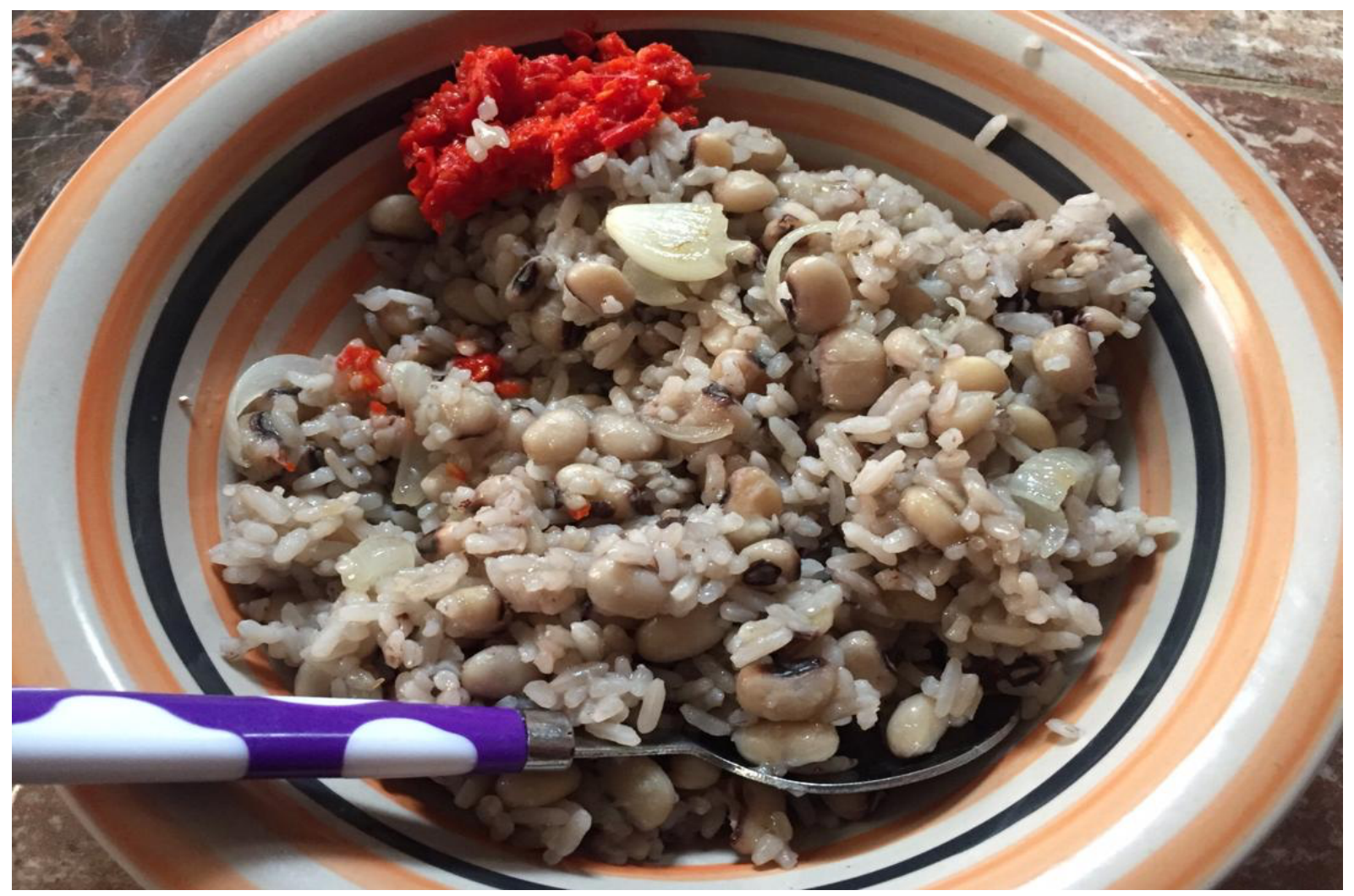

Fig 3 Waakye, a Ghanaian dish made with rice and beans. Photo credit: Maha Patrick 

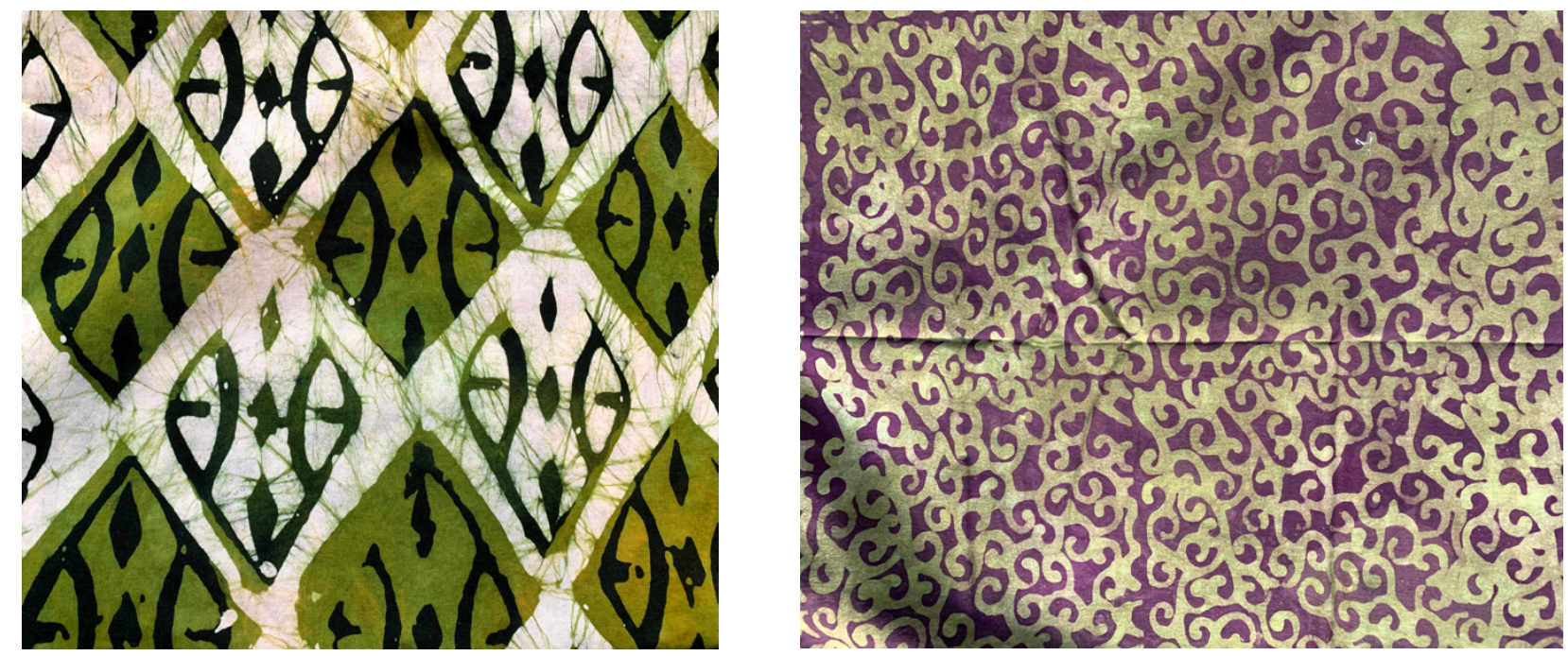

Fig 4 Two examples of batik fabric, which are found in markets across West Africa
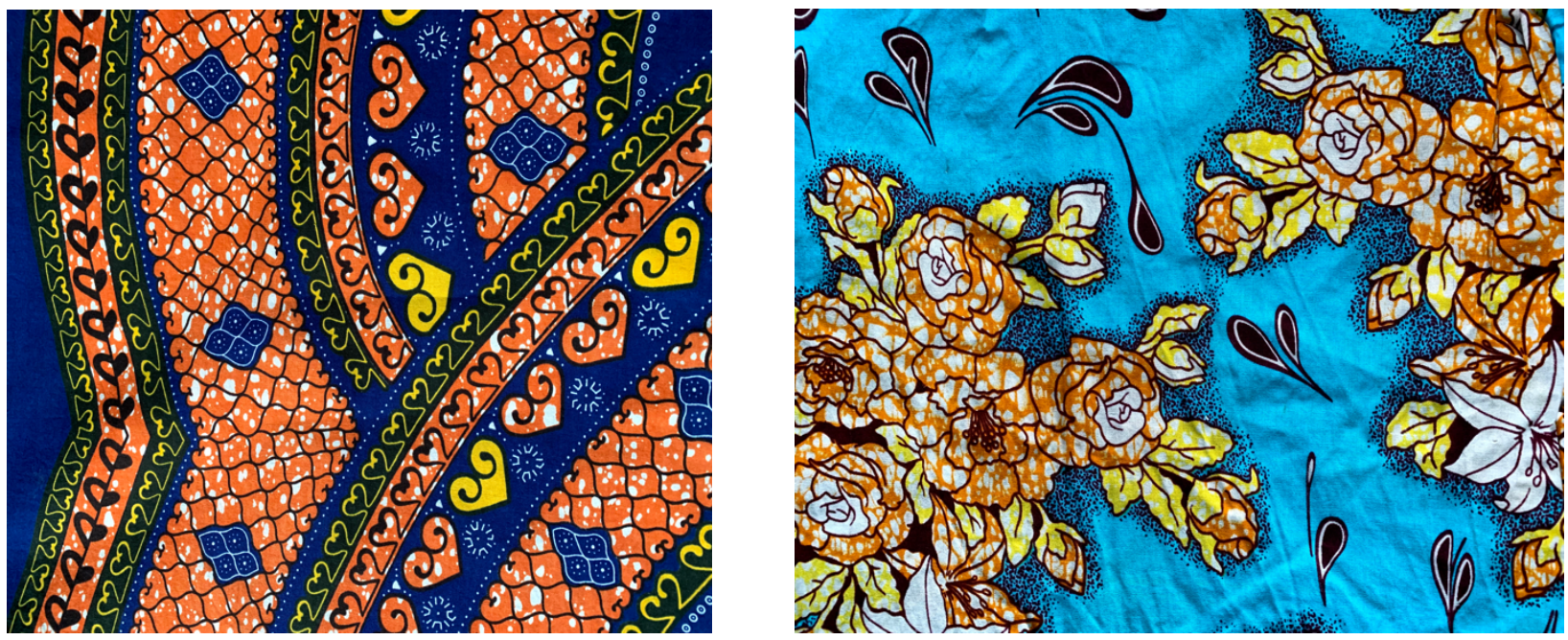

Fig 5 Two examples of wax print fabric, which are found in markets across West Africa
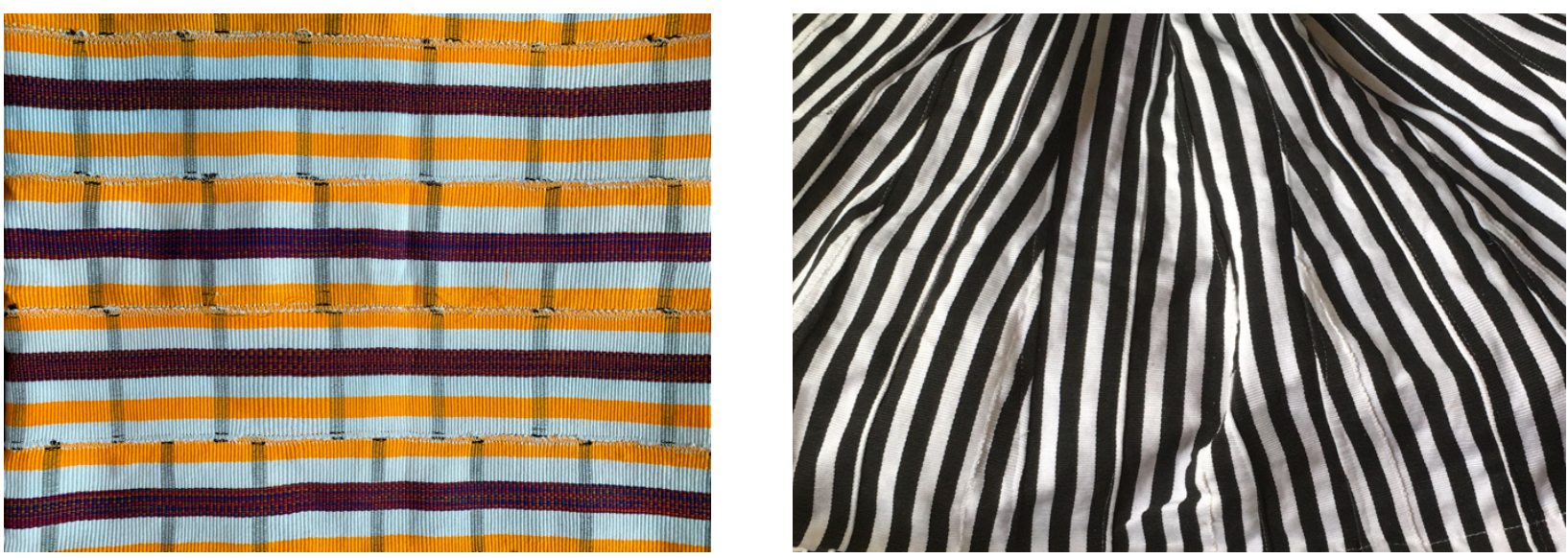

Fig 6 Two example of kente cloth which is traditionally made in Northern Ghana 
The swearing-in ceremony was the final event of pre-service training and occurred on 14 December 2017. In Peace Corps Ghana, the official swearing-in ceremony occurs at the American Ambassador's Residence in Accra followed by a celebration in the training community for the volunteers and their host families. For the ceremony, we wore clothing made by local seamstresses in fabric that our host families selected (Figure 7).

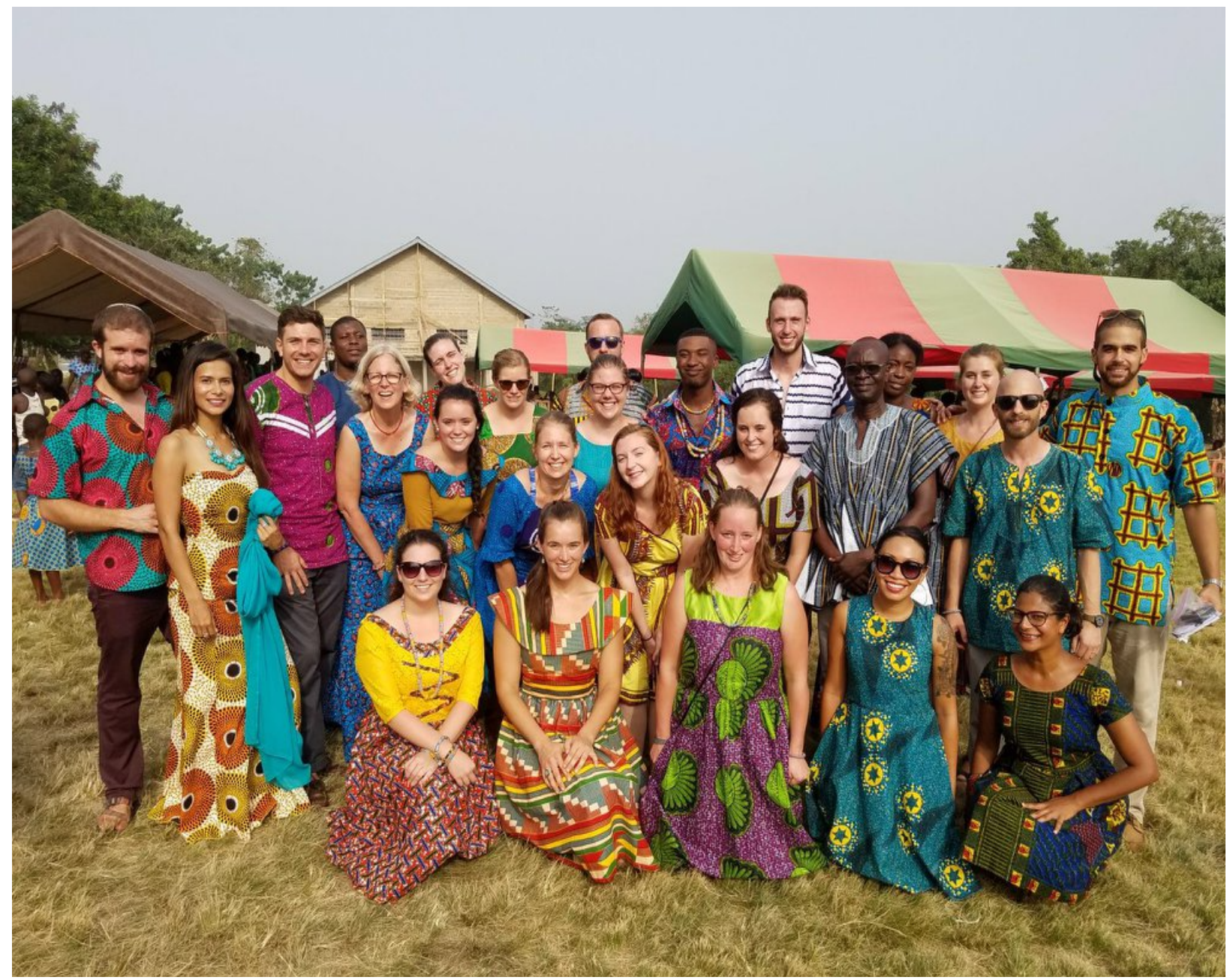

Fig 7 My cohort in Anyinasin, Ghana after the Swearing-In Ceremony on 14 December 2017. I am in the middle of the third row, with a bright blue top

\section{Year One Projects}

The first three months of a Peace Corps volunteer's service is called Site Integration. During this period, the volunteers are expected to focus on integration with their community and hold community meetings to determine which projects the community is interested in. After three months volunteers attend the Reconnect In-service Training with the rest of their cohort. The point of this training is to allow the new volunteers to reconnect with their cohort and discuss any issues or successes with staff members. The training usually includes additional technical 
sessions. For our Reconnect conference we spent two days at the Center for No Till Agriculture in Kumasi learning about conservation agriculture and no-till practices.

After Reconnect is finished, volunteers start working on projects and writing grant applications to fund projects in their communities. The first project I worked on was to have the water from my community's borehole tested for contaminants. People in my community were interested in a community garden but were concerned about the water quality from the borehole. They had heard that borehole water was not always conducive to growing vegetables. I took a water sample to the Northern Region Water Quality Laboratory run by World Vision, where they tested the water for different contaminants. The water was found to be safe for gardening, so my counterpart and I started to develop a plan for a dry season community garden. For the dry season garden, I wrote a grant of approximately $\$ 500$ to purchase seeds, fencing materials, and a hand pump for watering the garden. The grant was funded by the Feed the Future Initiative, a project run by the United States Agency for International Development, in partnership with Peace Corps Ghana. The grant was approved and the materials purchased in October 2018, and the garden was established in November 2019.

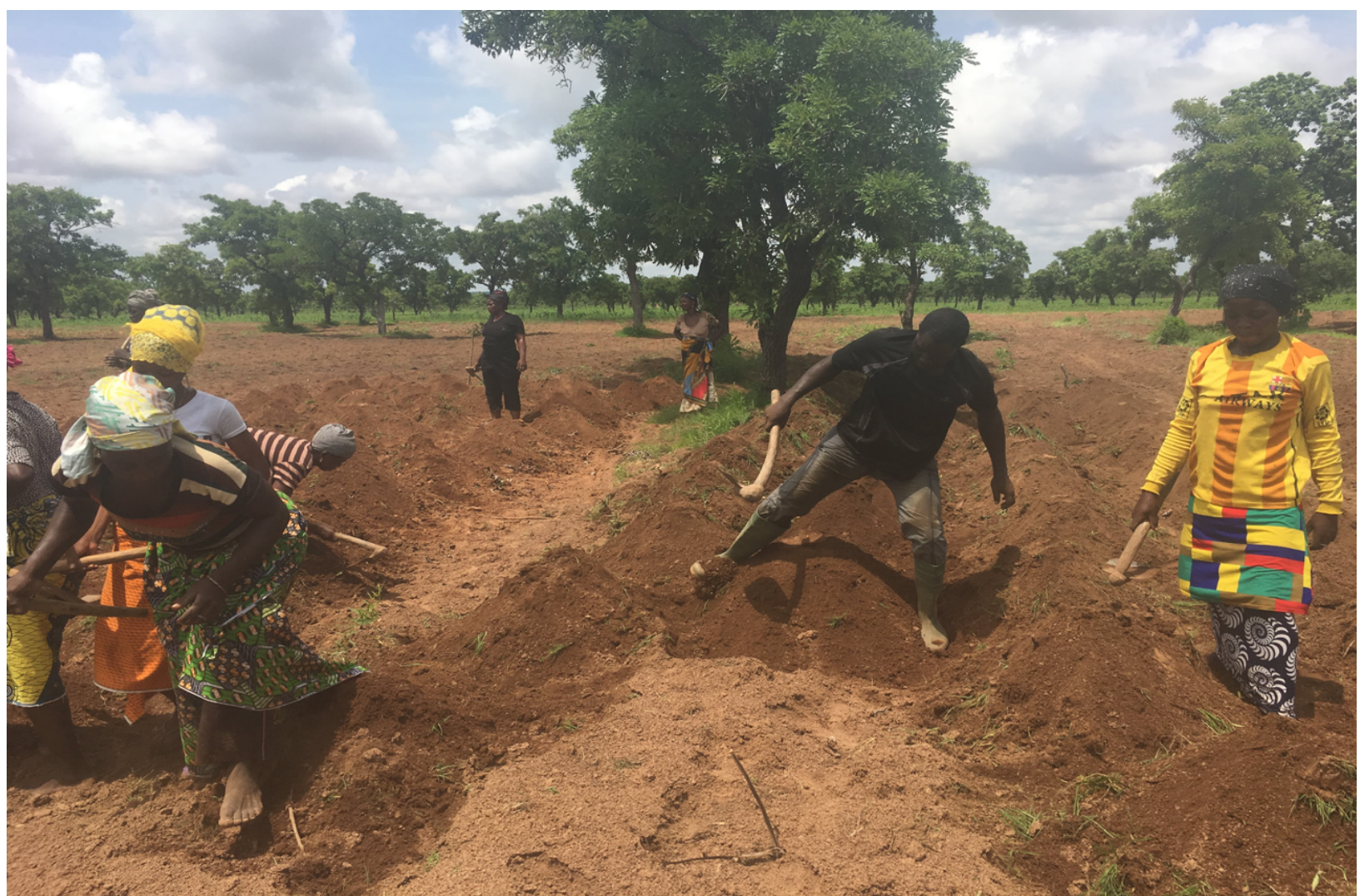

Fig 8 My counterpart and some of the women's group using hoes to dig ridges and mounds for the sweet potatoes, July 2018 in Kpataribogu, Northern Region 
The other main project that I worked on during my first year was growing orange flesh sweet potatoes with a women's group in my community. The project was a joint effort between Peace Corps and a United States Agency for International Development funded project called Resiliency in Northern Ghana. Resiliency in Northern Ghana was a five-year project that focused on nutrition projects as well as economic development. One of their main programs was working with women's groups throughout the Northern Region to grow orange flesh sweet potatoes to improve household nutrition and create additional income. During my first year of service, which was Resiliency in Northern Ghana's last year of funding, they decided to work directly with volunteers to provide sweet potato vines to volunteer communities. As part of this project Peace Corps volunteers and their counterparts attended a training in Tamale where we learned the correct methods to plant and maintain orange flesh sweet potatoes during rainy season. We also learned how to preserve the vines over the dry season. Following training, we returned to our respective communities to prepare the land by digging ridges and mounds to plant the vines (Figure 8). Resiliency in Northern Ghana then distributed the vines and I went to the farm with the women's group from my community to plant them (Figure 9). Maintenance for the sweet potatoes only required that we weed the field twice and ensure that the ridges and mounds did not crack as the tubers grew. We were then able to harvest after about four months, which was in mid-November. From the half-acre of land that we planted, we were able to harvest about 2,100 $\mathrm{kg}$ of tubers (Figure 10). A week after harvest, we held a cooking demonstration, where the women prepared local dishes using

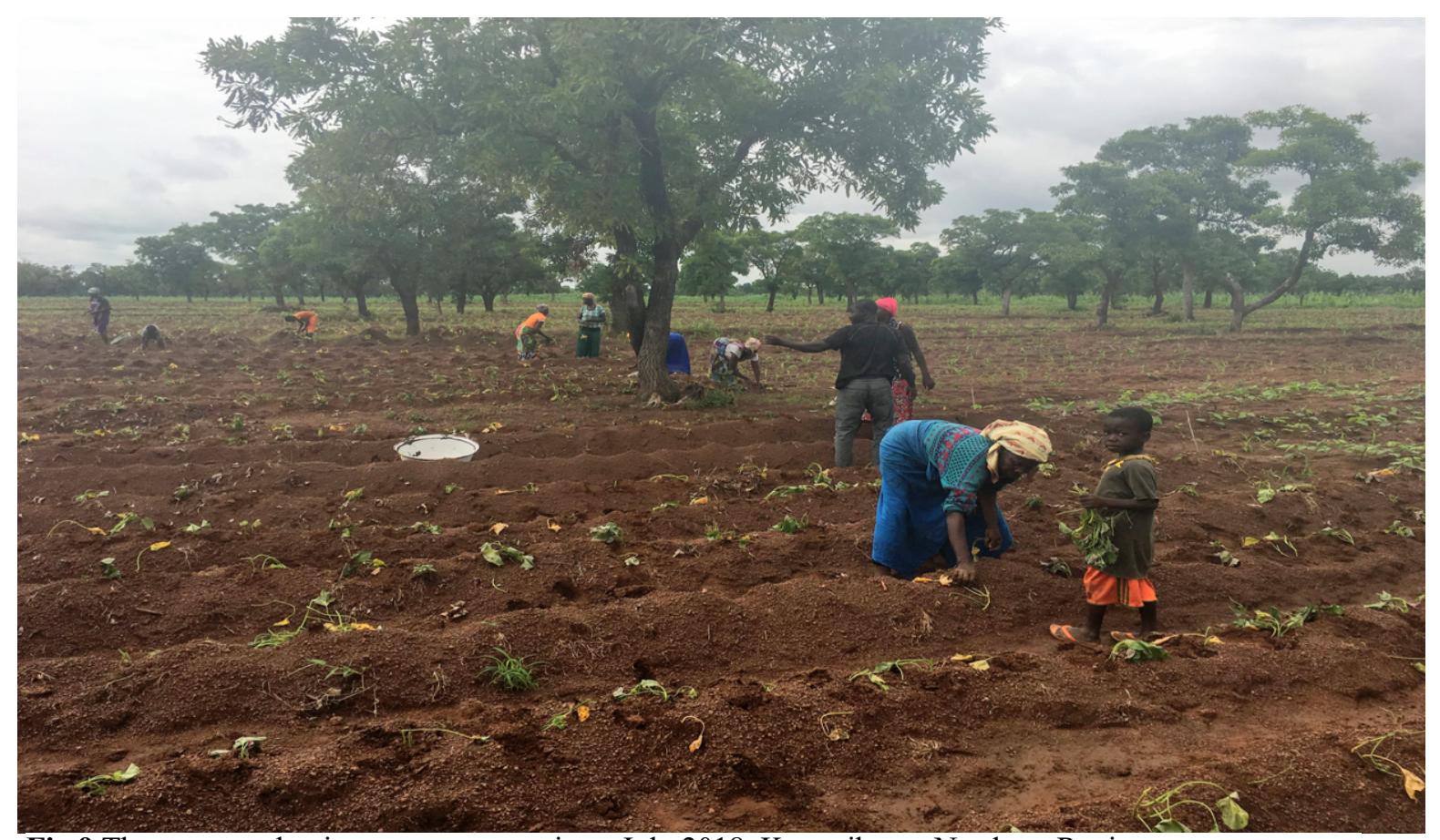

Fig 9 The women planting sweet potato vines, July 2018, Kpataribogu, Northern Region 
the orange flesh sweet potatoes. The cooking demonstration was also used to celebrate the harvest. Not long after we harvested, I traveled to Kumasi in the Ashanti Region for my cohort's mid-service training.

Mid-service training occurred approximately half way through service. We discussed what we accomplished over the first year of service as well as any challenges or security issues that had arisen. We also did some more technical training involving business literacy. After mid-service training, I then traveled back to the United States for the holidays and returned to Ghana in early January 2019.

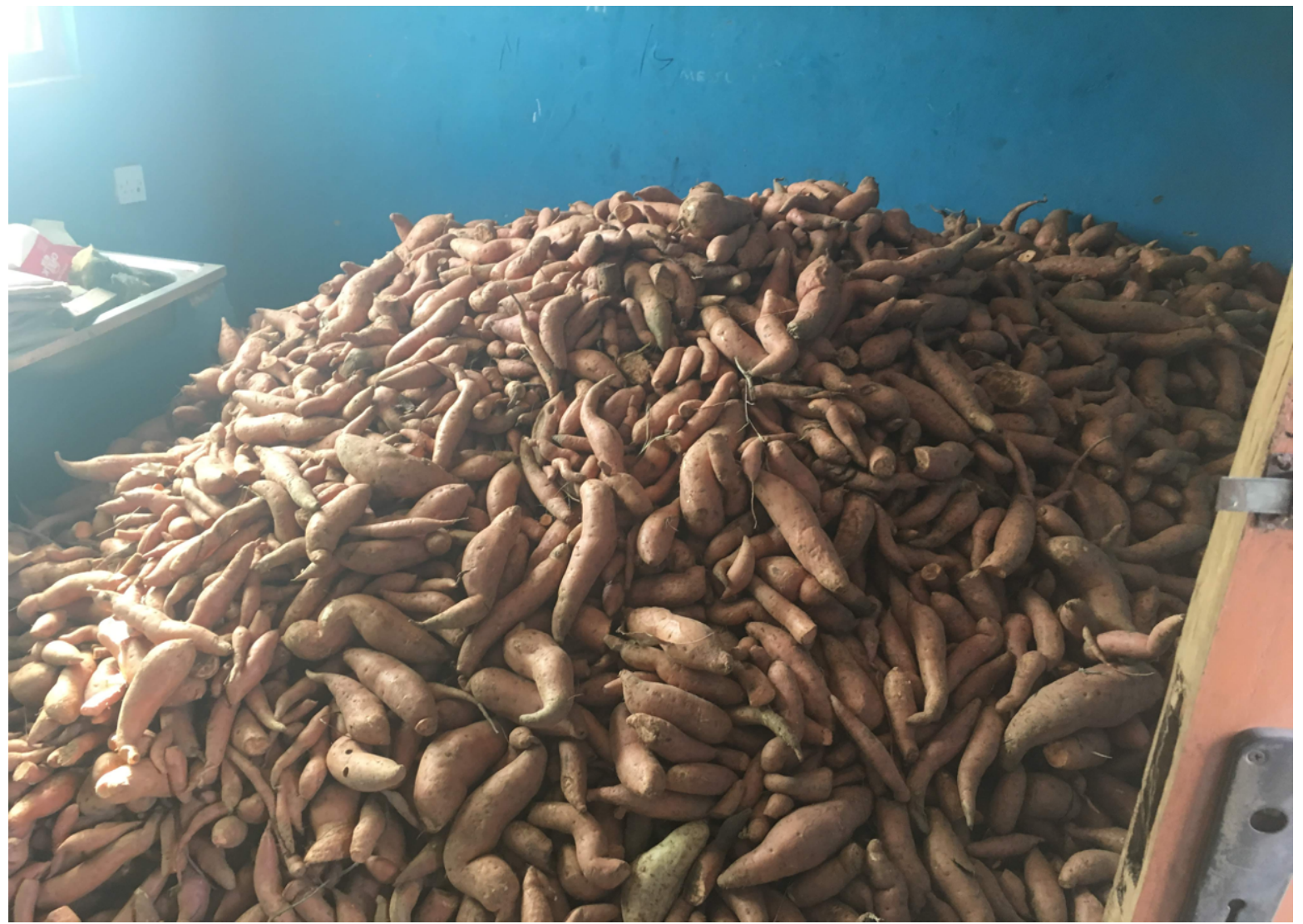

Fig 10 Approximately $2100 \mathrm{~kg}$ of sweet potato tubers that were harvested by the women's group, November 2018, Kpataribogu, Northern Region

\section{Year Two Projects}

The first several months of my second year as a volunteer in Ghana were busy. I applied and was selected to work as a Peace Corps Volunteer Trainer, along with another member from my cohort, for the new group of agriculture volunteers. The new group of agriculture volunteers arrived in Ghana on 15 January 2019 along with the new group of health volunteers. As a trainer, I was responsible for helping with the technical sessions and acting as a resource for the trainees. We were there primarily to answer questions about what life was like in Ghana. I traveled back and forth from my community to the training community in Eastern Region from January through March, 
switching off duties with the other trainer. While I was in the training community, I helped with the practical agriculture sessions and answered questions about my own experiences and projects as well as what volunteer life was like in general. On 28 March 2019 the new group of agriculture and health trainees swore in as volunteers.

When I returned to my community following pre-service training, I started working with two other volunteers, Connor Weis and Blaire Frett, to write a grant to purchase orange flesh sweet potato vines for our communities for the coming rainy season. Our grant, of approximately $\$ 1,500$, was approved and used to purchase over 52,000 vines for six different communities, transportation for the vines to each community, and funding for the volunteers and counterparts from participating communities to travel to Pishigu in the Northern Region for a halfday training. The training was led by my counterpart, Musah, and Connor's counterpart, Lukman, both of whom had participated in the training led by Resiliency in Northern Ghana the previous year (Figure 11). The training included

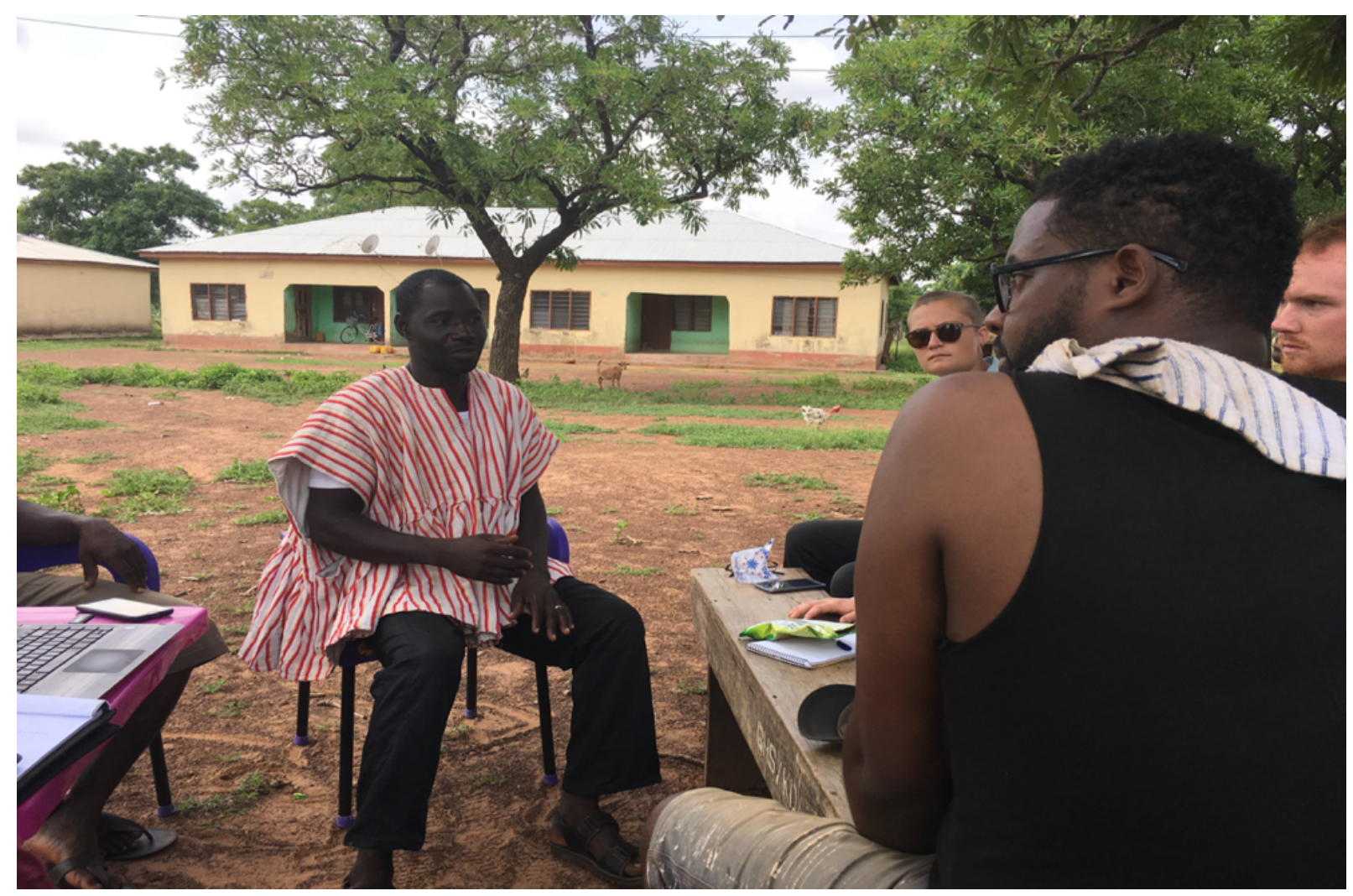

Fig 11 My counterpart teaching Peace Corps volunteers and their counterparts about orange flesh sweet potatoes at a training in Pishigu, Northern Region in July 2019

a practical demonstration of how to prepare the land for planting and how to plant the vines with the correct spacing (Figure 12). After the training was held, I traveled with my counterpart to Dalun, Northern Region to pick up the vines and transport them to each community. We had about 35 bags of vines to distribute between the six communities. The volunteers and their communities were able to plant the vines the following day. For the most 
part, harvest went well in each community. My community did not have a good harvest. It was difficult for the women to make time to go to the field to weed because they were busy on their families' farms. The lack of weeding led to a poor harvest because there was not enough sunlight or space for the sweet potato tubers to grow. The group in Pishigu had the same problem and did not have a great harvest. The other communities, though, were able to weed and had a good yield.

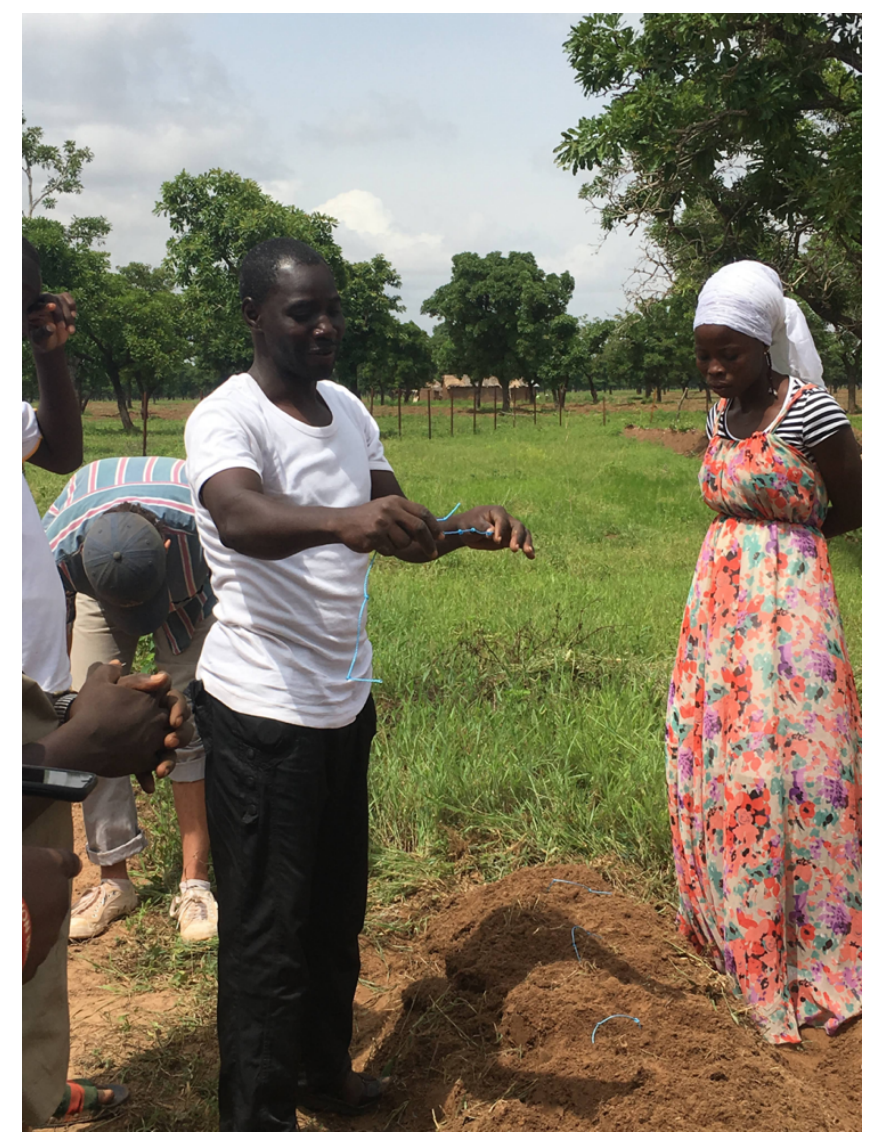

Fig 12 Musah using a piece of rope to show volunteers and counterparts the correct way to plant sweet potato vines. July 2019, Pishigu, Northern Region

During my second year, I also interviewed 87 farmers in 10 communities throughout Northern and Northeast Regions about bush burning practices. I spent ten days and traveled to six of those communities to do interviews. Three of the other communities I traveled to later and the last community was mine.

The last project I finished before leaving my community was the dry season garden, that I had written a grant for in my first year of service. In July 2019, we placed the sticks for the fencing and then in October we finished fencing the garden with wire fencing. After we attempted to harvest orange flesh sweet potato in November, we took some of the vines and placed them in the dry season garden so that they could be preserved with water from 
the nearby borehole (Figure 13). My counterpart and I finished planting the vines on 22 November 2019. I spent my last week cleaning and packing and saying goodbye to my community.

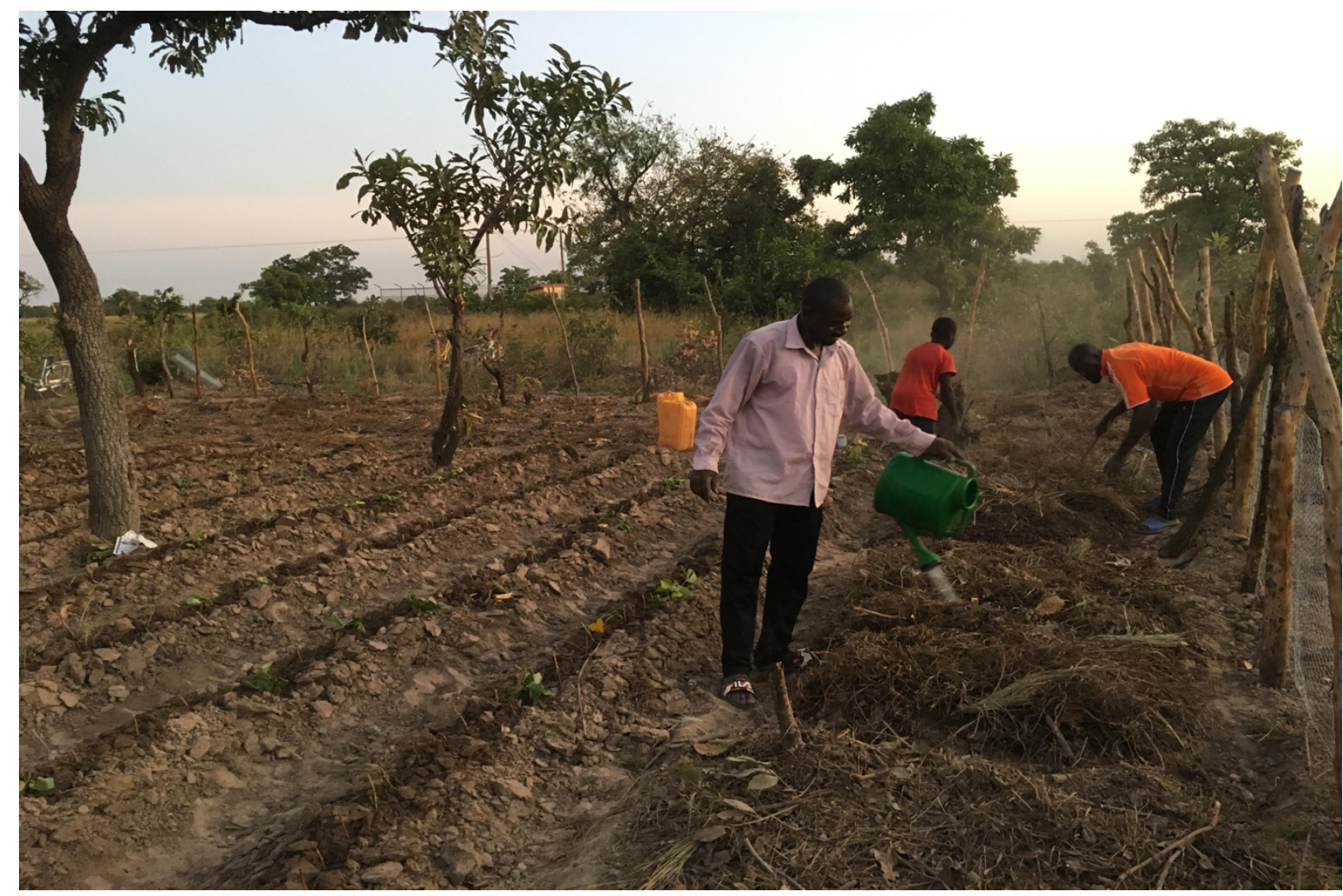

Fig 13 My counterpart, his son, and a friend planting sweet potato vines in the dry season garden, November 2019, Kpataribogu, Northern Region

\section{Overall Experiences}

Overall, I thoroughly enjoyed my experience in Ghana, and I would highly recommend Peace Corps to people who are interested in international development. I loved my community and always felt welcomed wherever I went. My counterpart was amazing and always enthusiastic about working on new projects and learning new agriculture techniques. My best friends in the community, other than my counterpart, were a group of girls who took it upon themselves to teach me Dagbani when I first arrived in Kpataribogu. I think my biggest success, in terms of projects, was with orange flesh sweet potato. The women that I worked with loved growing and eating the tubers so much the first year that they wanted to continue the project the following year. My counterpart also really enjoyed planting the sweet potatoes and was excited for the dry season garden, so there would be vines for the next rainy season. 
There are always challenges that come with Peace Corps, ranging from cultural differences to food and water-related illnesses. Throughout my service there were various challenges that I had to overcome. I gave myself food poisoning and managed to get Giardia at least once. In June 2019, due to serious security issues in Burkina Faso that were driving refugees over the border into Ghana, Peace Corps decided to evacuate all 37 volunteers in Upper East and Upper West Regions. As my community was in the Northern Region, I was not evacuated. However, the evacuation included many people from my cohort and many people from the agriculture group that I had helped to train. Most of the volunteers from my cohort were sent home because they were five months away from being finished. Some of the newer volunteers were able to be placed in new communities but several also went home. It was difficult to see many of my friends forced to leave their communities abruptly. The biggest challenge of my service came about a month before I finished. A member of my cohort, and one of my friends, was medically evacuated to South Africa where she passed away a week later after an accident in her home. It was incredibly difficult to deal with her loss and to see so many of my other friends hurting. It was remarkable to me how my cohort came together to comfort and help each other to process (Figure 14).

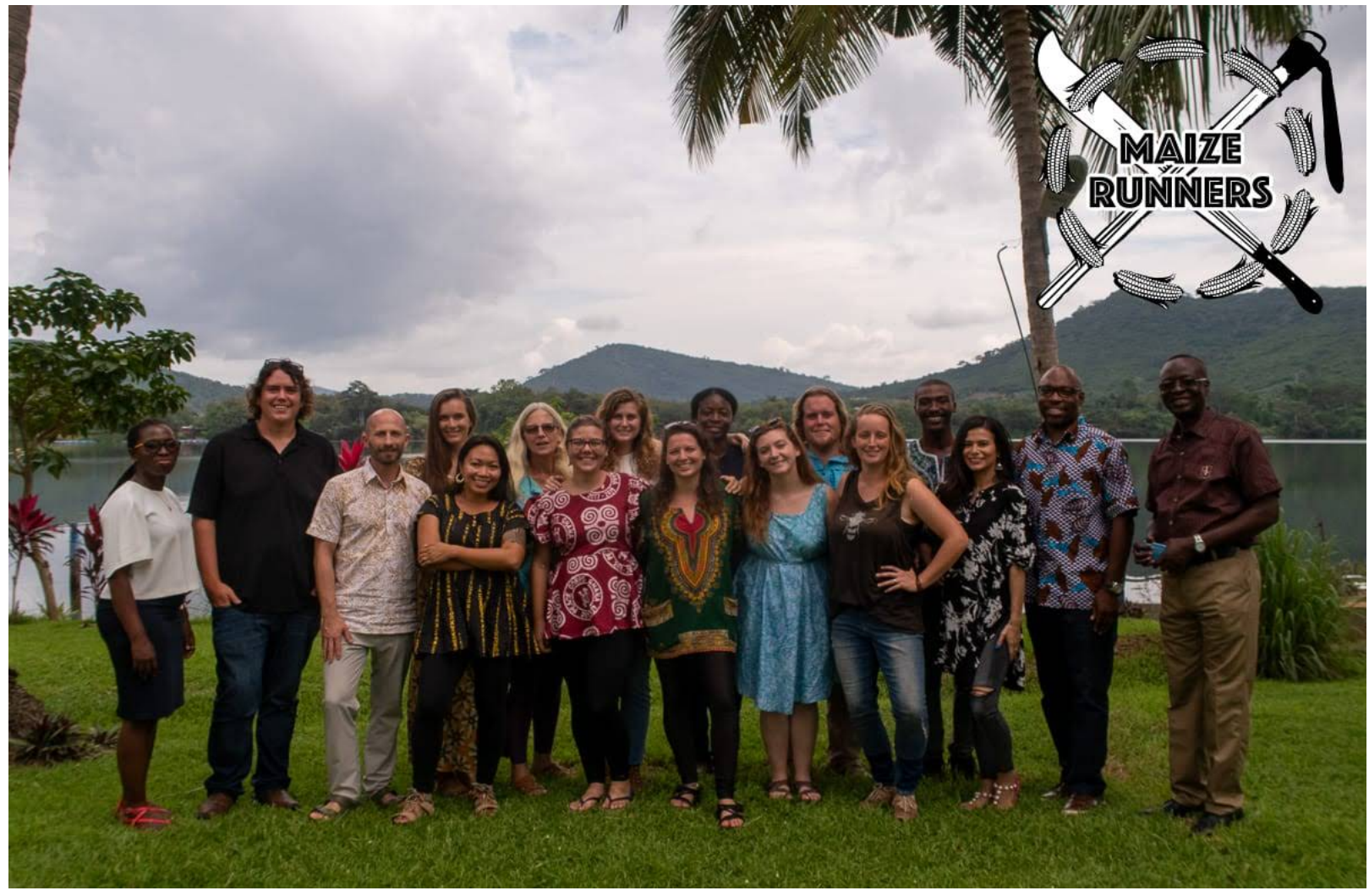

Fig 14 My cohort at our close of service conference on Volta Lake, Ghana in September 2019. Photo and Logo Credit: Kurt Uhlendorf 
Despite those challenges, I am grateful for my experiences in Ghana and with Peace Corps. I am grateful for the other members of the Peace Corps community and my friends in Kpataribogu and the Northern Region.

Peace Corps is a life changing experience that I will never forget. 


\section{Literature Cited}

JFK Library. 2020. Peace Corps: history. Retrieved 4 February 2020, from https://www.jfklibrary.org/learn/aboutjfk/jfk-

inhistory/peacecorps?gclid=Cj0KCQiApt_xBRDxARIsAAMUMuNuLUIVwKI_Ae7iWYud91IkXuERFd GkvozQ3_DfHnebRDIg-KkaAjIxEALw_wcB

Peace Corps. 2020a. Peace Corps: history. Retrieved 4 February 2020, from https://www.peacecorps.gov/about/history/

Peace Corps. 2020b. Ghana: about. Retrieved 4 February 2020, from https://www.peacecorps.gov/ghana/about/ Peace Corps. 2020c. Peace Corps: preparation and training. Retrieved 4 February 2020, from https://www.peacecorps.gov/volunteer/preparation-and-training/ 


\title{
Chapter 2
}

\section{Perceived Effects of Bush Burning on Agricultural}

\author{
$\underline{\text { and Wildlife Resources in Ghana }} \mathbf{1}^{1}$
}

${ }^{1}$ This Chapter is written in the style of Food Security 
Perceived Effects of Bush Burning on Agricultural and Wildlife Resources in Ghana

Caitlin Wilson, M. S. ${ }^{1}$

Donald J. Brown, Ph. D. ${ }^{1}$

Ida Holaskova, Ph.D. ${ }^{1}$

Steven Selin, Ph.D. ${ }^{1}$

James T. Anderson, Ph.D. ${ }^{1}$ jim.anderson@mail.wvu.edu

\author{
${ }^{1}$ West Virginia University \\ Davis College of Agriculture, Natural Resources and Design \\ Division of Forestry and Natural Resources \\ Morgantown, West Virginia, USA
}




\begin{abstract}
Fires are a key aspect of savanna ecology, but current anthropogenic uses of bush burning are causing soil degradation and a decrease in food security in northern Ghana. We interviewed 87 farmers on their bush burning behavior to determine if demographic factors influenced the reasoning behind farmers bush burning practices. Interviews took place in ten communities across the Northern Region using Barrier Analysis Surveys. Results were both quantitative and qualitative. Data analysis was conducted using logistic regression modeling. The number of participants categorized as burners or non-burners were modeled using demographic information and participants' perceptions of the effects of bush burning. Models were selected based on $\triangle \mathrm{AICc}$ and weight. We were able to determine some of the motivations people had to practice or not practice bush burning. Motivations to avoid bush burning included the perceived severity of its effects on agriculture and wildlife, the perceived lack of effectiveness, perceived negative consequences, and access to tools and materials. Motivations to use bush burning included perceived effectiveness and perceived positive consequences. We were also able to determine participants' perceptions of the effects of bush burning on their farms and for wildlife. Participants noted a variety of negative consequences such as impacts to crop yield, income, soil fertility, and erosion as well as some positive consequences such as benefits to seed germination and ease of use to clear land for farming. Participants also provided some strategies to discourage the use of bush burning. Providing better access to conservation agriculture education and punishing those caught bush burning could discourage people from and therefore potentially increase their household's income and food security.
\end{abstract}




\section{Introduction}

Savannas are unique ecosystems as they are the only major biome characterized by the codominance of two types of vegetation: grass and trees (Laris 2011). Fire plays an important role in maintaining savanna ecosystems by affecting the ratio of grasses to trees and preventing succession to a full canopy forested ecosystem (Andersen et al. 2005; Caillault et al. 2015; Furley et al. 2008; Laris 2011). On the African continent, savannas are the largest physical ecosystems in the western, central and southern regions. Savannas naturally evolved due to the frequency of dry lightning storms that encourage an ecosystem dependent on fire (Eriksen 2007).

African savannas account for the majority of global vegetation fires (72\%, Kugbe et al. 2012). Fires can have natural causes such as lightning strikes, but many are caused by anthropogenic factors. Across West Africa, people in rural areas set fires in the savanna to clear land, hunt, gather, pasture cattle and other livestock, and reduce the intensity of natural fires (Caillault et al. 2015). Bush burning has been practiced in West Africa for nearly six millennia and can be dated back to the first Neolithic settlement on the continent (Caillault et al. 2015). Research indicates that low-intensity fires at specific points during the dry season can reduce fuel load, lower pest populations, replenish soil with nutrients, and encourage plant diversity (Andersen et al. 2005; Furley et al. 2008).

In the savanna ecological zone of Ghana, bush fires occur during the dry season, typically between November and February (Kugbe et al. 2012; Kugbe et al. 2015). Most fires in northern Ghana have anthropogenic causes such as clearing land for agriculture, hunting, and promoting grass regrowth for animal feed (Kugbe et al. 2012). Research has tied the frequency and intensity of bush burning practices in rural communities to degradation of soil fertility in northern Ghana (Bagamsah 2005; Kugbe et al. 2012; Laris 2011). During a fire, nutrients from the soil are transferred to the atmosphere as particulate debris. Many of these nutrient particles are then deposited near the burn area. However, nitrogen and carbon, which are more volatile, are transported farther from the site of the fire. Even if nutrients are deposited close to the fire, they are more susceptible to erosion from runoff (Bagamsah 2005). Analysis of soil from a protected grove near Tamale, Ghana showed that the soil organic matter content was $13.1 \%$ (Korem 1989). Nearby soil that was subjected to annual burns had a soil organic matter content of only $1.8 \%$ (Korem 1989). In another study of savanna fires in the Congo it was found that annual burning transferred $85 \%$ of nitrogen, $25 \%$ of phosphorus, $39 \%$ of potassium, $21 \%$ of calcium, and $28 \%$ of magnesium into the atmosphere (Laclau et al. 2002). 
Bush fires also impact albedo, or the amount of solar radiation that is reflected by the land (Bagamsah 2005). Pre-fire and post-fire albedo values from a study in northern Ghana were $0.16-0.22$ and $0.06-0.08$ respectively (Bagamsah 2005). This pattern of decreasing post-fire albedo values was also recorded in studies of Australian (Beringer et al. 2003) and South African (Scholes and Walker 1993) savannas. The decrease in albedo is ecologically important because it links the bush fires with the ability of the land to reflect solar radiation. The inability of the land to reflect solar radiation leads to an increase in soil temperature, which then affects biological processes such as seed germination, root growth, and microbial activity (Mathias et al. 2000; Potter et al. 1987). Decreased soil fertility, reduced albedo, and changes in the types of vegetation present have been noticed by the people of Ghana (Yiran et al. 2012). Participants in a study about land degradation said they had noticed decreases in the quantity and quality of vegetation, firewood, and grass for thatch roofing. Participants had also noticed decreased soil fertility and inconsistent rainfall that was affecting crop yield. The signs of land degradation that participants had noticed were then verified using satellite imagery of the area. The study used satellite views of the Upper East Region of Ghana to show changes in land cover, vegetation density and type, and burn scars from bush burning (Yiran et al. 2012).

Farmers in West Africa, including Ghana, are subsistence farmers reliant on the nutrients in the soil because access to fertilizers and improved seed is cost prohibitive (Jalloh et al. 2013; Kugbe et al. 2015). With soil fertility degrading, prices rising for fertilizer and improved seeds, and an increasing population in the area, farmers in northern Ghana are challenged with producing enough food (Kugbe et al. 2015). Food security in the area is a tenuous situation with the anthropogenic impacts of agriculture in Sub-Saharan Africa leading to soil acidification, soil erosion, and loss of organic matter and nutrients (Oyekale 2016; Vlek et al. 2010). Land management practices of farmers in the area are unsustainable and are contributing to the loss of soil fertility and food security (Oyekale 2016; Vlek et al. 2010).

Some research has been conducted to understand the motivations of people to use bush burning. One study in Zambia compared indigenous and colonial fire regimes and the ecosystem effects of both (Eriksen 2007). The study found that indigenous fire regimes within the Kafinda Game Management Area and Kasanka National Park were usually managed with an understanding of environmental conservation. People in the area burned at different points throughout the year depending on their purpose. Bush burning was used as a way to encourage vegetation regeneration, prevent more destructive fires, control pests and weeds, promote species diversity, as well as to create 
animal pasture and clear land for farming. However post-colonial fire regimes discouraged bush burning and altered local regimes to either exclusively late dry-season fires or complete fire suppression (Eriksen 2007). Other research indicates that people primarily use bush burning in agriculture or for hunting rather than as management for the savanna ecosystem (Oyekale 2016; Vlek et al. 2010).

Understanding the motivations behind bush burning practices can help to tailor future programs to encourage people to stop bush burning or alter bush burning practices. The United States Agency for International Development has developed twelve motivations or determinants that define people's behavior including perceived self-efficacy or skills, social norms, positive consequences, negative consequences, susceptibility or risk, severity, action efficacy, divine will, policy, culture, access, and cues for action (Davis 2004; Kittle 2013). The determinant of perceived self-efficacy or skills is based on a person's set of knowledge, skills, and ability to perform a behavior. Perceived social norms are based on an individual's perception of what other people think of their behavior, particularly others who are important to the individual. The culture determinant is like perceived social norms as it is based on the surrounding customs and values of a group or society. Perceived positive and negative consequences are closely tied and are related to what individual's view as the positive or negative results of their behavior (Davis 2004; Kittle 2013). Perceived susceptibility or risk is the level of risk the person believes they are facing by practicing a behavior. The individual's idea of how severe the problem or behavior is serves as the basis for the perceived severity determinant. While perceived susceptibility or risk and perceived severity are tied to the problem, perceived action efficacy ties the behavior to the problem, because it is the individual's perception of how effective their behavior is in addressing the problem (Davis 2004; Kittle 2013). The individual's religion and belief in a higher power determines how their perception of divine will affects their behavior. Policy can also affect a person's behavior as well as the access a person has to resources. Access is based on barriers like cost, transportation, gender, language, and cultural issues. Having reminders or cues can change a person's behavior by reminding them to do, or not do, an activity. These cues can be events in a person's life that then remind them to behave in a certain manner. During a barrier analysis survey, participants are asked a series of questions to ascertain important determinants for their behavior (Davis 2004; Kittle 2013).

We used a barrier analysis survey, adapted to bush burning behavior, to conduct interviews of farmers in the Northern Region of Ghana. The objectives of our study were to: 1) examine the motivations of farmers in northern Ghana to practice or not practice bush burning; 2) assess their perceptions of the impacts of bush burning; 
and 3) compare participant responses from the Barrier Analysis survey based on their classification as either burner or non-burner.

\section{Materials and Methods}

\section{Study Area}

Northern Ghana is divided into three regions: Upper West, Upper East, and Northern. We conducted our study in the Northern Region (Figure 1). The Northern Region is the largest region, with a landmass of 70,384 $\mathrm{km}^{2}$ and a population of 2.5 million people (Bediako 2011; Northern 2017). Tamale is the regional capital and is the largest city in northern Ghana. The Northern Region primarily consists of the Dagomba, Mampruli, and Gonja tribes. Agriculture is the main land use (Northern 2017). The most commonly grown crops are maize (Zea mays), millet (Pennisetum glaucum), groundnut (Arachis hypogaea), soybean (Glycine max), and yam (Dioscorea rotundata) (Heve et al. 2016). Crop production is limited due to high temperatures, which can exceed $40^{\circ} \mathrm{C}$, and low rainfall for most of the year (Heve et al. 2016). The average annual rainfall in Tamale between 1981 and 2000 was $77.3 \mathrm{~mm}$ compared to the average annual rainfall in Accra which was $260.5 \mathrm{~mm}$ during the same time period (Owusu and Waylen 2009). Soil is gravelly, with high hematite and illite content which causes low soil organic matter content (Heve et al. 2016).

We selected ten communities in the savanna agro-ecological zone of the Northern Region to participate. The Dagomba communities were Pishigu, Kpataribogu, Langogu and Tong in Karaga District; Dalun, Wuba, and Bong Naa Yili in Kumbungu District; and Gbulahago in Tolon District. Daboya \#2 and Boamasse were Mampruli communities in the West Mamprusi District (Table 1). Agriculture is the primary source of income for most people. A Peace Corps volunteer was present in each community to facilitate coordination with the community.

\section{Barrier Analysis Surveys}

We conducted barrier analysis surveys of bush burning practices by farmers via an interview process in the ten communities in August 2019. We chose communities by asking Peace Corps volunteers (PCV) to participate and included those who responded. The PCV present in each community asked farmers to volunteer to participate in the interviews. We then traveled to each community to conduct interviews of the farmers who were interested in participating. In cases where it was necessary, a translator from the community was used for the surveys. We also 
electronically recorded the interviews after obtaining permission from the participant. The interviews were recorded to increase accuracy during data analysis.

The survey consisted of three sections: Demographic, Screening, and Research (Appendix I). In the first section (Demographic Questions 1-10) we collected demographic information from the farmers. This included their name, approximate age, gender, community, tribe, years of farming experience and number of acres farmed.

Number of acres farmed was defined as the number of cropped acres and did not include livestock acreage because livestock typically do not have dedicated pasture and roam freely in the community. The second section consisted of four questions about participants past and present use of bush burning on their farms or to hunt (Screening Questions 1-4). Responses to these questions classified the participants as either a burner or non-burner. The third section (Research Questions 1-19) was comprised of 19 questions that focused on participants reasoning for their behavior. The questions in the third section of the survey were aimed at different motives to identify the reasoning for each participant's behavior regarding bush burning. Eight of the questions required yes or no responses and 11 were open-ended.

\section{Data Analysis}

We used logistic regression modeling to analyze data. We chose research question 3 (Do you think bush burning has a negative effect on your farm?), research question 4 (Do you think that bush burning has a negative effect on wildlife?), and research question 10 (Do you think God approves or disapproves of bush burning?) for modeling, because they summarized participant perceptions of bush burning. We used participant responses to selected research questions along with age of participants, years of farming experience, and the number of acres farmed as predictor variables. Our response variables were participants categorized as burners or non-burners for each question. For research question 3, which related to farming, only participants who burned for farming were labeled as burners. Analyses for research question 4 labeled only those participants who used bush burning to hunt as burners and research question 10 used all participants who used bush burning whether for farming or hunting. We ranked candidate models using Akaike's information criterion corrected for small sample size (AICc), $\triangle \mathrm{AICc}$, and weight of the model. We selected the most complex model with a $\triangle \mathrm{AICc}$ value of $<2$ and an $85 \%$ confidence interval of each relevant predictor was used to assess the strength of the individual predictors (Arnold 2010). We selected the most complex model with a $\triangle \mathrm{AICc}$ of $<2$ because our objective was to determine the motivations to use bush burning. By using the most complex model, with more predictors, that still had strong $\triangle \mathrm{AICc}$ we were able to 
determine more motivations than by selecting a model with fewer predictors even if it was stronger. We used descriptive statistics for the remaining research questions. For open-ended questions, we categorized participants' responses based on overall themes to allow for statistical analyses (Table 2). We analyzed data using the SAS Categorical Data Manual (Stokes et al. 2012) and JMP (JMP®, Version Pro 14.0, SAS Institute Inc., Cary, NC, Copyright (C2015).

\section{Results}

\section{Participant Demographics and Burning Behavior}

We surveyed 87 participants from ten different communities and four districts of the Northern Region of Ghana. There were two participants from Gbulahago, five from Langogu, and ten each from Pishigu, Bong Naa Yili, Wuba, Dalun, Boamasse, Daboya \#2, Tong, and Kpataribogu. There were 20 participants from the Mampruli tribe and 67 from the Dagomba tribe. Of the 87 participants, 12 were women (14\%) and 75 were men (86\%). Participants ranged from 20 to 75 years of age $(\overline{\mathrm{x}}=38.81, \mathrm{SD}=13.31)$. Every participant farmed and 12 participants $(14 \%)$ hunted. Years of farming experience ranged from 1 to 50 years $(\overline{\mathrm{x}}=17.45$ years, $\mathrm{SD}=11.05)$ (Figure 2$)$ and the number of acres farmed ranged from 1 acre to 100 acres $(\bar{x}=10.80$ acres, $S D=12.32)$. Of the 87 participants, $72 \%$ $(n=63)$, of those interviewed were categorized as non-burners and $28 \%$ were burners $(n=24)$. Of those who were burners $(n=24), 50 \%(n=12)$ used bush burning on their farms, $29 \%(n=7)$ used bush burning to hunt, and $21 \%(n$ =5) used bush burning for farming and hunting (Figure 3).

\section{Attitudes towards Bush Burning}

The majority of the participants responded that they viewed the effects of bush burning on agriculture and wildlife negatively. Seventy-six participants (88\%) viewed the effects of bush burning on their farms negatively and a similar number of participants $(\mathrm{n}=75,86 \%)$ said that bush burning negatively affected wildlife. Most $(\mathrm{n}=82$, 94\%) also said that bush burning was not helpful on the farm or for hunting $(\mathrm{n}=61,70 \%)$. When asked about perceived consequences, the majority of participants responded that there were no benefits from bush burning. The other 20 participants (23\%) listed benefits for bush burning, including benefits for hunters, clearing the land, seed germination, pest control, and shea tree production (Vitellaria paradoxa). The rest of the participants stated a variety of negative consequences, including burned crops, homes, people, animals (both wild and domesticated), beneficial insects like bees, and grasses used for roof thatching and for animal feed. Participants also mentioned that it was 
difficult to control the spread of fire and that bush burning was causing increased erosion, desertification, and decreasing soil fertility.

Most participants $(\mathrm{n}=71,82 \%)$ said that they were able to properly care for their farms with their current knowledge, skills, and resources. The use of fire belts as protection, knowledge of the consequences of bush burning, available resources, and education made it easy for participants to avoid using bush burning. The ease of use and the benefits to seed germination made it easy for participants to use bush burning. Lack of money, tools and materials, and education as well as difficulty protecting farmland and the danger of other people setting fires made it difficult for participants to avoid using bush burning. Ease of use and the benefits of bush burning also made it difficult for participants to avoid bush burning.

Every participant in Gbulahago and Dalun stated that their communities had rules in place to prevent people from bush burning. Participants in Pishigu all said that were no community rules against bush burning. Those in Wuba, Bong Naa Yili, Boamasse, Daboya \#2, Tong, Langogu, and Kpataribogu gave a mix of yes and no responses and there was no unanimous answer as to whether or not the communities had any rules in place. Participants also gave mixed answers about whether or not there were cultural taboos against bush burning in Pishigu, Wuba, Dalun, Boamasse, Daboya \#2, Tong, Langogu, and Kpataribogu. Interviewees in Gbulahago and Bong Naa Yili consistently answered that their communities did have taboos against bush burning.

Sixty-nine respondents (79\%) stated that their friends, family members, and opinion leaders, disapproved of bush burning. Eighteen participants (21\%) indicated that there were some people in their lives who approved of bush burning. All of the participants in the survey were Muslim. Seventy-seven participants (89\%) said that Allah, or God, disapproved, nine (10\%) said that Allah approved, and one (1\%) participant was unsure.

Fifty-two participants (60\%), found their bush burning behavior easy to remember, whether or not they were burners or non-burners. Thirty-four participants (39\%), burners and non-burners found it difficult to remember. One participant (1\%) said that they hired people to work on the farm and was unsure if it was difficult or easy to remember. Thirty-six participants (41\%) said it was easy to access necessary equipment and 50 participants (58\%) said it was difficult. One participant (1\%) gave no response.

\section{Predicting Bush Burning Behavior}

The logistic regression model selections indicated that research question 3 (Do you think that bush burning has a negative effect on your farm?) and 10 (Do you think God approves or disapproves of bush burning?) had a 
strong influence on whether or not an individual was a non-burner, but research question 4 (Do you think that bush burning has a negative effect on wildlife?) did not (Table 3). Additive models containing number of acres farmed for research question 3 and years of farming experience for research question 10 also had support (Table 3; $\triangle \mathrm{AICc}<2$ ), but the coefficient confidence intervals for the farming predictors overlapped 0 (Table 4). For research question 4 , age of participants was the only variable with strong support, and the coefficient confidence interval did not overlap 0 (Table 4). Participants that farmed larger areas were less likely to use bush burning (Figure 4). Older participants had a lower probability of using bush burning for hunting than younger participants (Figure 5). Participants had a lower probability of using bush burning, for either farming or hunting, with more years of farming experience and if they thought that God disapproved of bush burning (Figure 6).

\section{Perceived Effects of Bush Burning on Farming and Hunting}

Of the 16 species of animals participants hunted, $38 \%$ of the respondents hunted rabbit (Lepus victoriae) (Figure 4). Rat (Fukomys zechi) $(\mathrm{n}=4)$ and grasscutter (Thryonomys swinderianus) $(\mathrm{n}=4)$ were each hunted by $14 \%$ of the respondents. Other less commonly harvested species included lizards (Agama agama; Varanus exanthematicus), bush Guinea fowl (Numida meleagris), mouse (Arvicanthis niloticus; Mus haussa), squirrel (Heliosciurus gambianus; Funisciurus substriatus), parrot (Psittacus erithacus princeps), goat (Capra hircus), and various birds (Bubulcus ibis; Strix woofordii; Lophoceros camurus; Corvus albus).

Participants who hunted were aware of a change in wildlife populations over the years they hunted. The majority, $74 \%(n=14)$, responded that they had noticed reduced numbers of animals. Two participants (10\%) noted that there was a reduction in the variety of species they saw while hunting. One participant (5\%), said that they had observed a reduction in the habitat available to the animals they hunted. Two other participants (10\%) indicated that they had not noticed a change over the years they had been hunting. Participants' responses indicated that they perceived bush burning to have a negative effect on the wildlife surrounding their communities. Responses also indicated that the majority perceived that bush burning did not help people to hunt, but there were some that believed bush burning was helpful when hunting.

Participants stated that bush burning was reducing soil fertility, burning crops, and increasing desertification. They also noted threats to trees, animal fodder, family income, and community resources. Participants in the study specifically mentioned the negative effects bush fires had on shea trees. People noted a decrease in crop yield and therefore their household income. The few interviewees that said that bush burning was 
helpful stated that fire was beneficial for seed germination and as an easy and cost-effective method to clear farm land. Despite participants noting many negative effects of bush burning, the majority of respondents stated they were able to properly care for their farms. People indicated other issues, such as access to tractors and chemical fertilizers as well as changing rainfall patterns, that made it difficult to farm in the area.

\section{Future Behavior Change}

Education using a variety of methods was the most commonly $(59 \%, n=57)$ suggested strategy to encourage people to stop bush burning (Table 5). Participants suggested using community meetings or informal gatherings to discuss consequences of bush burning and encourage their friends and family to stop bush burning. Other responses indicated that working with farmers to provide alternative methods and materials like fire belts and chemical fertilizers and herbicides could be effective $(3 \%, n=3)$. Participants also noted that using punishments such as fines with enforcement from the chief and elders in each community would help to discourage people from starting fires $(22 \%, \mathrm{n}=21)$. Participants said that education and knowledge of the consequences of bush burning was what made it easy for them to avoid bush burning the majority of the time.

Access to tools and materials like tractors, fertilizers, and herbicides is difficult and expensive for many of the farmers interviewed. Many of the participants said that it was difficult to obtain what they needed to avoid bush burning on their farms. Those who did practice bush burning said it was easy for them to access tools like matches that would facilitate bush burning practices. Matches can be easily found in communities, but tractors and chemicals are not as easily available. The lack of access to equipment and chemicals was stated as the main reason people had difficulty avoiding bush burning and the ease of access to matches and other materials like dried grasses and old tires made it easy for people to practice bush burning.

\section{Discussion}

Overall participants in the study had an awareness of the negative effects that bush burning has on their crops and on wildlife. They discussed a decrease in soil fertility, an increase in erosion and desertification, as well as decreases in wildlife populations and habitat degradation. Even the participants, who practiced bush burning were aware of the negative consequences. The participants perceptions of the change in crop yield over the years and in connection with bush burning is substantiated by scientific studies that demonstrated decreasing soil nutrient content and albedo (Bagamsah 2005; Heve et al. 2016; Kugbe et al. 2012; Kugebe et al. 2015). Participants noted that bush 
burning affected shea trees, which are a culturally significant agricultural resource. One study found that bush fires during the flowering period of shea trees caused a significant decrease in fruiting (Tom-Dery et al. 2017). Shea butter is produced from the fruit for local markets as well as for global consumption. Shea is an important cultural and economic resource for West Africa especially as it is a way for women to have additional income to supplement their household income and have some financial independence (Tom-Dery et al 2017).

\section{Participant Attitudes towards Bush Burning}

The majority of participants were aware of the severity and the risks associated with bush burning for farming and for hunting. Participants also were aware of a variety of consequences resulting from bush burning. The range of responses showed that participants were thinking of consequences for themselves, like loss of income, crops, and homes, as well as consequences for the surrounding environment such as a decrease in soil fertility and an increase in erosion and desertification. Other studies can corroborate participants' perceived consequences from this study. Several studies have shown that frequent bush burning in rural communities in northern Ghana has led to soil degradation and loss of fertility (Bagamsah 2005; Kugbe et al 2012; Laris 2011). Participants in another study in northern Ghana also showed the same perception of land degradation specifically in the quantity and quality of vegetation in the surrounding area (Yiran et al. 2012).

Social and cultural norms seemed to have little effect on participants behavior. Each participant that used bush burning knew someone in their lives that disapproved of bush burning or knew of cultural taboos or community rules prohibiting bush burning. Responses indicated that cues or reminders for their bush burning behavior, depending their classification as a burner or non-burner, also did not have much of an effect. However, the modeling results showed that participants were affected by their perceptions of the effects of bush burning as well as their age, years of farming experience, and the number of acres farmed. Participants that had more years of experience, larger farms, and viewed the effects of bush burning negatively were less likely to use bush burning. We speculate that participants with more experience, as well as being older, were less likely to use bush burning because they had seen reduced crop yields and other negative effects of routine bush burning throughout their years of farming. It also makes sense that participants who viewed the effects of bush burning negatively would be less likely to use it for farming or hunting because they saw no benefit for the action. Religion also seemed to affect participants, as those that stated God disapproved of bush burning were less likely to conduct bush burning on their farm or for hunting. Participants indicated that lack of resources, whether money, education, or tools, made it 
difficult to avoid using bush burning. The ease of using bush burning also made it difficult for participants to avoid using bush burning because it is much more cost and labor effective than chemical or alternatives using tractors.

One study researching behavioral factors affecting the adoption of sustainable agriculture practices by farmers found similar motivations behind people's behavior (Dessart et al. 2019). Motivations such as perceived risks, costs and benefits, a farmer's knowledge, personality, as well as farming objectives and concern for the environment all affect whether or not a farmer would voluntarily adopt a new sustainable farming practice. If a farmer perceived a new practice to have little benefit and a high risk, they would be less likely to adopt the practice. However, if there was pressure for social approval or strong concern for the environment, a farmer would be more likely to adopt a new practice (Dessart et al. 2019). Similarly, in this study, a farmer's bush burning behavior was driven by their perception of risk, the costs and benefits, as well as social or religious pressure. Whether or not participants in this study used bush burning, their choice of behavior was driven by a combination of dispositional factors, such as personality and risk aversion, social factors, such as need for approval, and internal cognitive factors, such as knowledge (Dessart el al. 2019). An earlier study (Beedell \& Rehman 1999) also found similar connections between various behavioral factors. Adoption of conservation practices on farms, depended on a farmer's community and social groups, as well as the individual's knowledge and personality. Factors such as the size of a farm alone could not explain a farmer's behavior (Beedell \& Rehman 1999).

\section{Bush Burning and Food Security}

Bush burning is one of the most cost and labor effective methods for clearing farmland after harvesting. For the farmers of Ghana, this is important because they rely on subsistence farming for food and income for their households (Jalloh et al. 2013). There is little money to spare on expensive chemical fertilizers and herbicides or for mechanized low-till methods. In Ghana, there are few resources for low till and conservation agriculture. The Ministry of Food and Agriculture and the Howard G. Buffet Foundation: Center for No Till Agriculture have programs relating to conservation agriculture, but they do not reach a wide audience (Howard G Buffet Foundation: Center for No Till Agriculture 2020; Ministry of Food and Agriculture 2017). The Center for No Till Agriculture, located near Kumasi, Ashanti Region, is far from the participants of this study and is difficult as well as expensive for them to reach. The Ministry of Food and Agriculture has extension agents assigned to districts in every region of Ghana (Ministry of Food and Agriculture 2017). However, the extension agents are responsible for many communities and it is difficult for them to ensure every farmer in their area receives the resources they need 
(Ministry of Food and Agriculture 2017). Increasing access to conservation agriculture education and the tools needed to practice the techniques could decrease the number of people who practice bush burning.

Participants were aware of the negative consequences of bush burning on wildlife. Respondents indicated that they were aware of decreasing wildlife populations as well as habitat degradation. People reported that they saw fewer animals overall and fewer species when hunting. However, participants also indicated that bush burning was helpful during hunting by causing wildlife to flee to where hunters would be waiting to kill them. Bush meat in Ghana is an important source of protein for many households (Cowlishaw et al. 2005). Reduced numbers of animals present for hunting can affect household food security. Economically, bush meat is an extensive industry in Ghana and some depend on the extra income from selling the meat they hunted (Cowlishaw et al. 2005). With decreases in wildlife populations and crop yield due to continued burning, most farmers in the northern Ghana are in precarious economic and food security situations.

The consequences of bush burning for many participants in this study had economic and food security implications. The government of Ghana defines food security as food of good quality that provides the necessary nutrition, is available for purchase hygienically, at any point in the year in sufficient quantities, and at affordable prices (Adu et al. 2018). Currently many agricultural products, such as cereal crops and vegetables, in northern Ghana do not meet those standards, leaving people food insecure. Cereal crops like maize and millet are commonly farmed and are used as the base for most dishes but are not nutritious (Heve et al. 2016). Nutritious starch alternatives like orange flesh sweet potato and vegetables can be expensive and difficult to find. The three northern regions of Ghana; Upper East, Upper West, and Northern Region have the highest poverty and food insecurity rates in the entire country (Adu et al. 2018). Participants in this study indicated a loss of income through a decrease in crop yield as well harvest loss from fires. In both situations, the loss of income contributes to the household's food insecurity. With the loss of the harvest, families lose food as well as the money that they would have received for selling the crop. Households have less food to consume and less money to purchase additional food. Having money to purchase additional food is important for the people in northern Ghana. Reduced access to bush meat also has an effect on household security due to the reduced access to protein as well as additional income from selling bush meat (Cowlishaw et al. 2005).

\section{Bush Burning and Gender}


Gender plays an important role in this study and in agriculture throughout Ghana (Doss et al. 2014; Opoku \& Glazebrook 2018). Typically, women, though heavily involved in farming activities, are not land owners and therefore are not responsible for the decisions made on the farm (Doss et al. 2014). Because of this, women tend to be underrepresented in studies such as this, where the majority of participants were men. Women farmers also tend to be more vulnerable to changing environments and poor crop yield because they are less financially secure than their male counterparts (Doss et al. 2014; Opoku \& Glazebrook 2018). Though organizations are trying to address gender inequality, more needs to be done in the field of agriculture especially in regard to climate change (Doss et al. 2014; Opoku \& Glazebrook 2018). Women's ability to control what happens on a piece of land can affect nutrition in the household. The children of women in Nepal were less likely to be malnourished if the women had access and control over farm land (Doss et al. 2014). In Ghana, women's land rights have broader household effects. Land rights can affect household nutrition and food expenditure because women cook for their entire households (Doss et al. 2014). With decreasing food security in the region, a changing climate, and decreasing crop yields due to bush burning and other environmental factors, it is important to give women more land rights and control over what crops are grown for their households.

\section{Conclusion}

The majority of participants in the study were aware of the negative consequences of bush burning. For those people that do bush burn it is difficult to switch to alternative conservation agriculture methods or chemical fertilizers and pesticides because bush burning uses the least labor and money. The use of bush burning impacts crop yield and increases food insecurity in one of Ghana's most food insecure regions. We were able to determine some of the motivations people had to practice or not practice bush burning as well as their perceptions of the effects of bush burning on their farms and for wildlife. Participants noted a variety of negative consequences such as impacts to crop yield, income, soil fertility, and erosion as well as some positive consequences such as benefits to seed germination and ease of use to clear land for farming. Motivations to avoid bush burning included the perceived severity of its effects on agriculture and wildlife, the perceived lack of effectiveness, perceived negative consequences, and access to tools and materials. Motivations to use bush burning included perceived effectiveness and perceived positive consequences. Demographic information such as years of farming experience, district, and age of participants as well as participants' perceptions of the effects of bush on agriculture and wildlife, and whether or not participants believed God approved or disapproved of bush burning affected the probability of a participant 
using bush burning. Participants also identified some strategies to discourage the use of bush burning. Providing better access to conservation agriculture education and punishing those caught bush burning could discourage people and therefore potentially increasing household's income and food security. 


\section{Acknowledgments}

We thank Peace Corps Ghana for their support of this project. We thank Matthew Walker for his assistance with statistical analyses. J. T. Anderson was supported by the National Science Foundation (01A-1458952) and the National Institute of Food and Agriculture (McStennis Project WVA00812) during manuscript preparation. 


\section{Literature Cited}

Adu, M.O., Yawson, D.O., Armah, F.A., Abano, E.E., Quansah, R. (2018). Systematic review of the effects of agricultural interventions on food security in northern Ghana. PLoS ONE 13(9).

Andersen, A.N., Cook, G.D., Corbett, L.K., Douglas, M.M., Eager, R.W., Russel-Smith, J., Setterfield, S.A., Williams, R.J., Woinarski, J.C.Z. (2005). Fire frequency and biodiversity conservation in Australian tropical savannas: implications from the Kpalaga fire experiment. Austral Ecology 30, 155-167.

Arnold, T.W. (2010). Uninformative parameters and model selection using Akaike's information criterion. Journal of Wildlife Management 74(6), 1175-1178.

Bagamsah, T.T. (2005). The impact of bushfire on carbon and nutrient stocks as well as albedo in the savanna of northern Ghana. Ecology and Development Series No. 25.

Beedel, J. D. C., and Rehman, T. (1999). Explaining farmers' conservation behaviour: Why do farmers behave the way they do?. Journal of Environmental Management 57, 165-167.

Bediako, G. (2011). 2010 Population and Housing Census: provisional results. Ghana Statistical Service.

Benjamini, Y., and Y. Hochberg. 1995. Controlling the false discovery rate: a practical and powerful approach to multiple testing. Journal of the Royal Statistical Society B 57, 289-300.

Beringer, J., Hurtley, L. B., Tapper, N. J., Coutts, A., Kerley, A., and Grady, P. O. (2003). Fire impacts on surface heat, moisture and carbon fluxes from a tropical savanna in northern Australia. International Journal of Wildland Fire, 12, 333-340.

Caillaut, S., Ballouche, A., Delahaye, D. (2015). Where are the "bad fires" in West African savannas? Rethinking burning management through a space-time analysis in Burkina Faso. The Geographical Journal, 181(4), 375-387. doi: 10.1111/geoj12074.

Cowlishaw, G., Mendelson, S., Rowcliffe, J. M. (2005). Structure and Operation of a Bushmeat Commodity Chain in Southwestern Ghana. Conservation Biology 19 (1), 139-149.

Davis Jr., T. P. (2004). Barrier Analysis Facilitator’s Guide: A Tool for Improving Behavior Change Communication in Child Survival and Community Development Programs, Washington, D.C.: Food for the Hungry. 
De La Cruz, N., Crookston, B., Dearden, K., Gray, B., Ivins, N., Alder, S., Davis, R. (2006). Who sleeps under bednets in Ghana? A doer/non-doer analysis of malaria prevention behaviours. Malaria Journal 5 (61), 1 11.

Dessart, F. J., Barreiro-Hurle, J., van Bavel, R. (2019). Behavioural factors affecting the adoption of sustainable farming practices: a policy-oriented review. European Review of Agricultural Economic 46 (3), 417-471.

Doss, C., Summerfield, G., Tsikata, D. (2014). Land, Gender, and Food Security. Feminist Economics, 20 (1), 1-23.

Eriksen, C. (2007). Why do they burn the 'bush'? Fire, rural livelihoods, and conservation in Zambia. The Geographic Journal, 173 (3), 242-256.

Furley, P.A., Reese, R.M., Ryan, C.M., Saiz, G. (2008). Savanna burning and the assessment of long-term fire experiments with particular reference to Zimbabwe. Progress in Physical Geography, 32(6), 611-634.

Heve, W.K., Olesen, J.E., Chirinda, N., Adik, G.K. (2016). Targeted management of organic resources for sustainably increasing organic carbon: Observations and perspectives for resource use and climate adaptations in northern Ghana. Soil and Plant Science, 66 (2), 178-190.

Howard G. Buffet Foundation: Center for No Till Agriculture. (2020). Retrieved from https://centrefornotill.org

Jalloh, A., Nelson, G.C., Thomas, T.S., Zougmore, R., Roy- Macauley, H. (2013). West African Agriculture and Climate Change. IFPRI Issue Brief, (75).

Kittle, B. (2013). A Practical Guide to Conducting a Barrier Analysis. New York, NY: Helen Keller International Korem, A. (1989). Revision of Ghana's Forest Policy. Land use, bushfires and the future of forest in Ghana, Symposia Series (III), 132-139.

Kugbe, J.X., Fosu, M., Desta, T.L., Denich, M., Vlek, P.L.G. (2012). Annual vegetation burns across the northern savanna region of Ghana: period of occurrence, area burns, nutrient losses and emissions. Nutrient Cycling in Agroecosystems, 93 (2), 265-284.

Kugbe, J.X., Fosu. M., Vlek, P.G. 2015. Impact of season, fuel load and vegetation cover on fire mediated nutrient losses across savanna agro-ecosystems: the case of northern Ghana. Nutrient Cycling in Agroecosystems, $102(1), 113-136$.

Laclau J-P, Sama-Poumba W, de Dieu Nzila J, Bouillet J-P, Ranger J. (2002). Biomass and nutrient dynamics in a littoral savanna subjected to annual fires in Congo. Acta Oecologica, 23, 41-50. 
Laris, P. (2011). Humanizing Savanna Biogeography: Linking human practices with ecological patterns in a frequently burned savanna of Southern Mali. Annals of the Association of American Geographers, 101 (5), 1067-1088, doi: 10.1080/00045608.2011.560063

Mathias, A. D., Fimbres, A., Sano, E. E., Post, D. F., Accioly, L., Batchily, A. K., Ferreira, L. G. (2000). Surface roughness effects on soil albedo. Soil Sci. Soc. Am. J., 64, 1035-1041.

Ministry of Food and Agriculture. (2017). Agricultural Sector Progress Report, 1-82

Northern Region Census Data. (2017, January 13). Retrieved from https://www.ghana.travel/places-tovisit/regions/northern/

Opoku, E., Glazebrook, T. (2018). Gender, Agriculture, and Climate Policy in Ghana. Environmental Ethics 40, $371-387$.

Owusu, K., Waylen, P. (2009). Trends in spatio-temporal variability in annual rainfall in Ghana (1951-2000). Weather, 62 (5).

Oyekale, A. S. (2016). Assessment of Sustainable Land Management and Food Security among Climatic Shocks’ Exposed to African Farmers. The Journal of Developing Areas. 50 (1), 319- 332.

Potter, K. N., Horton, R., Cruse, R. M. (1987). Soil surface roughness effects on radiation reflectance and soil heat flux. Soil Sci. Soc. Am. J. 51, 855-860.

Scholes, R. J. \& Walker, B.H. (1993). An African: Synthesis of Nylsvley Study. London, UK: Cambridge University Press.

Stokes, M. E., C. S. Davis and G. G. Koch. 2012. Categorical Data Analysis using SAS®, Third Edition. Cary, NC: SAS Institute Inc.

Tom-Dery, D., Eller, F., Reisdorff, C., \& Jensen, K. (2017). Shea (Vitellaria paradoxa C. F. Gaertn.) at the crossroads: current knowledge and research gaps. Agroforestry Systems, 92(5), 1353-1371. doi: $10.1007 / \mathrm{s} 10457-017-0080-\mathrm{y}$

Vleck, P.L.G., Le, Q.B., Tamene, L. (2010). Assessment of land degradation, its possible causes and threat to food security in Sub- Saharan Africa. In Food Security and Soil Quality (pp 57- 86). London, UK: CRC Press.

Yiran G.A.B., Kusimi, J. M., Kufogbe, S. K. (2012) A synthesis of remote sensing and local knowledge approaches in land degradation assessment in the Bawku East District, Ghana. International Journal of Applied Earth Observation and Geoinformation 14 (2012). Pp. 204-213. 


\section{Tables}

Table 1 The ten communities of the Northern Region, Ghana that, in 2019, participated in the barrier analysis study of bush burning, as well as their respective district, and approximate population as of the time of the survey. Surveys $(\mathrm{n}=87)$ were conducted through an interview process with farmers in each community that volunteered to participate

\begin{tabular}{llc}
\hline & Participating Communities, their District, and Approximate Population \\
\hline Community & District & Approximate Population \\
\hline Kpataribogu & Karaga & 1,400 \\
Pishigu & Karaga & 10,000 \\
Tong & Karaga & 1,700 \\
Langogu & Karaga & 2,000 \\
Bong Naa Yili & Kumbungu & 450 \\
Wuba & Kumbungu & 1,000 \\
Dalun & Kumbungu & 8,000 \\
Gbulahago & Tolon & 1,500 \\
Boamasse & West Mamprusi & 1,000 \\
Daboya \#2 & West Mamprusi & 1,200 \\
\hline
\end{tabular}

Table 2 The question number, question and coded response for each open-ended research question used in the barrier analysis surveys in 10 participating communities in the Northern Region, Ghana, 2019. Surveys $(\mathrm{n}=87)$ were conducted through an interview process with farmers in each community that volunteered to participate. Responses from the open-ended questions were coded based on overall themes present

\begin{tabular}{cll}
\hline \multicolumn{4}{c}{ Research Question and Coded Responses } \\
\hline Research Question Number & \multicolumn{1}{c}{ Question Text } & \multicolumn{1}{c}{ Responses } \\
\hline 1 & $\begin{array}{l}\text { How serious do you think bush } \\
\text { burning is in affecting your farm? }\end{array}$ & Negative \\
& Neutral \\
& Positive \\
& How serious do you think bush & Negative \\
burning is in affecting wildlife? & Neutral \\
& & Positive \\
& What makes it easy for you to & Knowledge of the consequences \\
& practice or not practice bush & Use of fire belts \\
burning? & Benefits for Seed Germination \\
& & Ease of use \\
& & Education \\
& & Matches \\
\hline
\end{tabular}




\begin{tabular}{|c|c|c|}
\hline & & Available resources \\
\hline & & Unsure \\
\hline \multirow[t]{7}{*}{9} & \multirow{7}{*}{$\begin{array}{l}\text { What makes it difficult for you to } \\
\text { practice or not practice bush } \\
\text { burning? }\end{array}$} & Lack of resources \\
\hline & & Knowledge of the consequences \\
\hline & & Benefits for Seed Germination \\
\hline & & Use of fire belts \\
\hline & & Ease of use \\
\hline & & Other people in the community \\
\hline & & Nothing \\
\hline \multirow[t]{3}{*}{11} & \multirow{3}{*}{$\begin{array}{l}\text { What do you think the benefits of } \\
\text { bush burning are? }\end{array}$} & No benefit \\
\hline & & Beneficial for hunting \\
\hline & & Beneficial for agriculture \\
\hline \multirow{11}{*}{12} & \multirow{11}{*}{$\begin{array}{l}\text { What do you think the } \\
\text { disadvantages of bush burning are? }\end{array}$} & Fire spreads \\
\hline & & Burns crops \\
\hline & & Decreases soil fertility \\
\hline & & Burns trees \\
\hline & & Fear of punishment if caught \\
\hline & & Burns grasses for roofing and \\
\hline & & $\begin{array}{l}\text { animal fodder } \\
\text { Harmful to people }\end{array}$ \\
\hline & & Reduces household income \\
\hline & & Harmful to animals \\
\hline & & Increased erosion \\
\hline & & No disadvantages \\
\hline \multirow[t]{8}{*}{19} & \multirow{8}{*}{$\begin{array}{l}\text { What strategies or interventions do } \\
\text { you think would be helpful in } \\
\text { encouraging people to stop bush } \\
\text { burning? }\end{array}$} & Education \\
\hline & & $\begin{array}{l}\text { Establish community rules and } \\
\text { punishments }\end{array}$ \\
\hline & & Supply tools and materials for \\
\hline & & alternative methods \\
\hline & & $\begin{array}{l}\text { Work together to put out fires and } \\
\text { catch those responsible }\end{array}$ \\
\hline & & Demonstration Plots \\
\hline & & Form Committee \\
\hline & & No suggestions \\
\hline
\end{tabular}


Table 3 Model selection results for research question 3 (Agriculture Perceptions), research question 4 (Wildlife Perceptions, and research question 10 (Religious Perceptions) from the barrier analysis surveys. Surveys were conducted in 10 communities in the Northern Region of Ghana in 2019. Surveys $(n=87)$ were conducted through an interview process with farmers in each community that volunteered to participate. Predictor variables for the models were years of farming experience, age of participants, district, participants' perceptions of the effects of bush burning on agriculture and wildlife, and if they thought God approved or disapproved of bush burning. The response variables were how participants were classified as burners or non-burners based on their response to the barrier analysis screening question and depending on whether the research question pertained to agriculture, hunting, or both. Models with $\triangle \mathrm{AICc}$ values $<2$ are good candidate models. We selected the model with the lowest $\triangle \mathrm{AICc}$ that was also contained the most variables. $*$ indicates selected model for parameter estimation

\begin{tabular}{|c|c|c|c|}
\hline Model & AICc & $\triangle \mathrm{AICc}$ & $\mathbf{W}_{\mathbf{i}}$ \\
\hline \multicolumn{4}{|l|}{ Agriculture Perceptions } \\
\hline Negative/Positive Effect on Farm & 78.4950 & 0 & 0.27908 \\
\hline Negative/Positive Effect on Farm + Number of Acres Farmed* & 79.5685 & 1.0735 & 0.16316 \\
\hline Negative/Positive Effect on Farm + Age of Participants & 79.7085 & 1.2135 & 0.15213 \\
\hline Intercept Only & 80.2813 & 1.7863 & 0.11424 \\
\hline Negative/Positive Effect on Farm + Years of Farming & 80.4011 & 1.9061 & 0.10760 \\
\hline \multicolumn{4}{|l|}{ Experience } \\
\hline Number of Acres Farmed & 81.2069 & 2.7119 & 0.07192 \\
\hline Age of Participants & 81.6717 & 3.1767 & 0.05700 \\
\hline Years of Farming Experience & 82.1173 & 3.6223 & 0.04562 \\
\hline \multicolumn{4}{|l|}{ Wildlife Perceptions } \\
\hline Age of Participants* & 63.367 & 0 & 0.50375 \\
\hline Intercept Only & 64.9015 & 1.5345 & 0.23389 \\
\hline Negative/Positive Effect on Wildlife + Age of Participants & 65.4308 & 2.0638 & 0.17950 \\
\hline Negative/ Positive Effect on Wildlife & 66.9769 & 3.6099 & 0.08286 \\
\hline \multicolumn{4}{|l|}{ Religious Perceptions } \\
\hline God Approves/Disapproves & 91.1543 & 0 & 0.24420 \\
\hline Intercept Only & 91.6489 & 0.4946 & 0.19070 \\
\hline God Approves/Disapproves + Years of Farming Experience* & 92.0067 & 0.8524 & 0.15946 \\
\hline God Approves/Disapproves + Number of Acres Farmed & 93.2335 & 2.0792 & 0.08635 \\
\hline God Approves/Disapproves + Age of Participants & 93.2979 & 2.1436 & 0.08361 \\
\hline Years of Farming Experience & 93.3409 & 2.1866 & 0.08183 \\
\hline Number of Acres Farmed & 93.3711 & 2.2168 & 0.08061 \\
\hline Age of Participants & 93.5624 & 2.4081 & 0.07325 \\
\hline
\end{tabular}


Table 4 The parameter estimate, standard error, and $85 \%$ confidence interval for each individual predictor from the selected models. Models were selected based on AICc, $\triangle \mathrm{AICc}$, and weight. Data for the models were taken from a barrier analysis study conducted in 10 communities in the Northern Region of Ghana in 2019. Surveys $(n=87)$ were conducted through an interview process with farmers in each community that volunteered to participate. Predictor variables for the models were years of farming experience, age of participants, district, participants' perceptions of the effects of bush burning on agriculture and wildlife, and if they thought God approved or disapproved of bush burning. The response variables were how participants were classified as burners or non-burners based on their response to the barrier analysis screening question and depending on whether the research question pertained to agriculture, hunting, or both. In JMP Pro 15 the parameter estimates for Negative/Positive Effects on Farm were based off of yes (there are negative effects) responses which were coded as 1. In JMP Pro 15 the parameter estimates for God Approves/Disapproves were based off of approved responses which were coded as 1

\begin{tabular}{lllll}
\hline Model & $\begin{array}{l}\text { Parameter } \\
\text { Estimate }\end{array}$ & $\begin{array}{l}\text { Standard } \\
\text { Error }\end{array}$ & $\begin{array}{l}\mathbf{8 5 \%} \text { CI } \\
\text { Lower } \\
\text { Limit }\end{array}$ & $\begin{array}{l}\mathbf{8 5 \%} \text { CI } \\
\text { Upper } \\
\text { Limit }\end{array}$ \\
\hline $\begin{array}{l}\text { Effects on Agriculture Perceptions } \\
\text { Negative/Positive Effects on Farm }\end{array}$ & 2.0225 & 1.0207 & 0.5527 & 3.4923 \\
Number of Acres Farmed & 0.0518 & 0.0457 & -0.0139 & 0.1176 \\
Effects on Wildlife Perceptions & & & & \\
Age of Participants & & & & \\
& 0.0641 & 0.0381 & 0.0092 & 0.1189 \\
Religious Perceptions & & & & \\
God Approves/Disapproves & & & & -0.1700 \\
Years of Farming Experience & -1.3301 & 0.8056 & -2.4902 & 0.0706 \\
\hline
\end{tabular}

Table 5 The number and percentage of participant responses to research question 19 (What actions, interventions, or strategies do you think would be effective in encouraging people to stop bush burning?). Surveys $(\mathrm{n}=87)$ were conducted through an interview process with farmers, in each community, that volunteered to participate. Participant responses were coded based on overall themes between the responses. Percentages are listed in each coded category from the barrier analysis survey conducted in 10 communities in the Northern Region of Ghana in 2019

\section{Responses to Research Question $19 \quad$ Number and Percentage of Responses}

\begin{tabular}{ll}
\hline Education & $57(59 \%)$ \\
Supply tools and materials & $3(3 \%)$ \\
Establish community rules and punishments & $21(22 \%)$ \\
Work together to put out fires & $9(9 \%)$ \\
Demonstration plot & $3(3 \%)$ \\
Form Committee & $2(2 \%)$ \\
No Response & $2(2 \%)$ \\
\hline
\end{tabular}




\section{Figures}

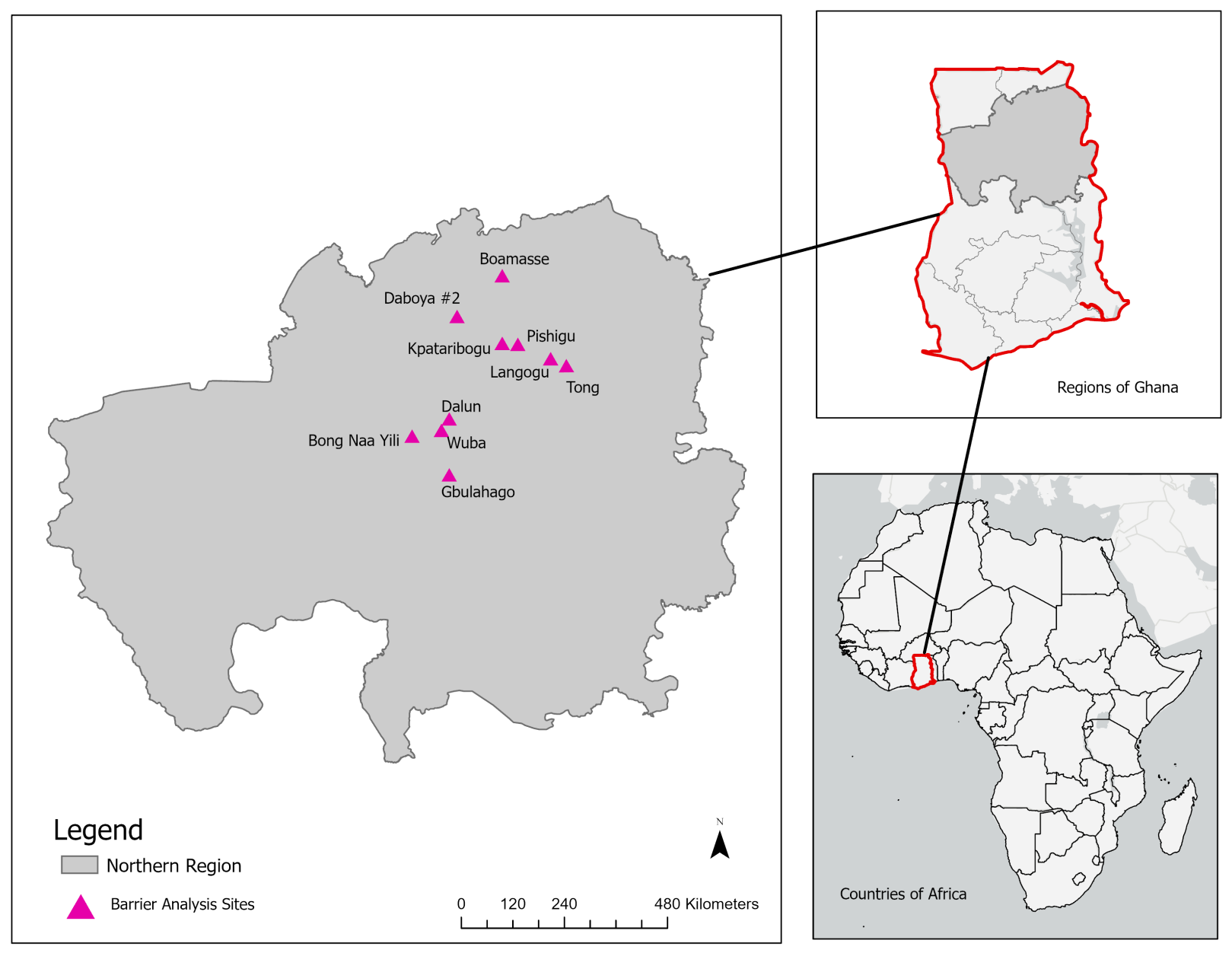

Fig 1 Map depicting the location of Ghana on the African continent and the 10 participating communities from the Northern Region that were surveyed during this study, 2019 


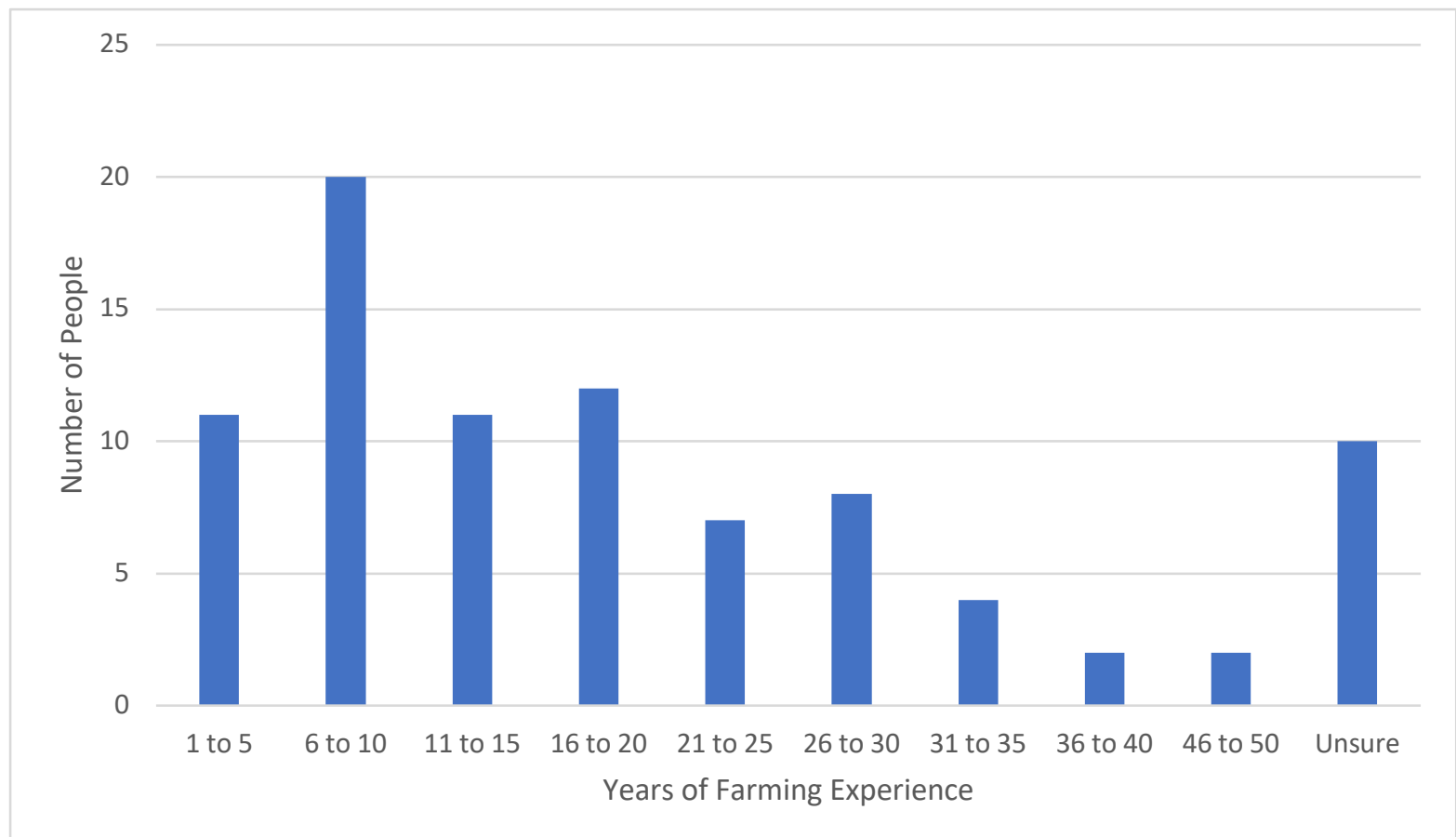

Fig 2 The number of participants by their years of farming experience, in groupings of five years, from the 10 participating communities in the Northern Region, Ghana, 2019. Surveys $(n=87)$ were conducted through an interview process with farmers in each community that volunteered to participate 


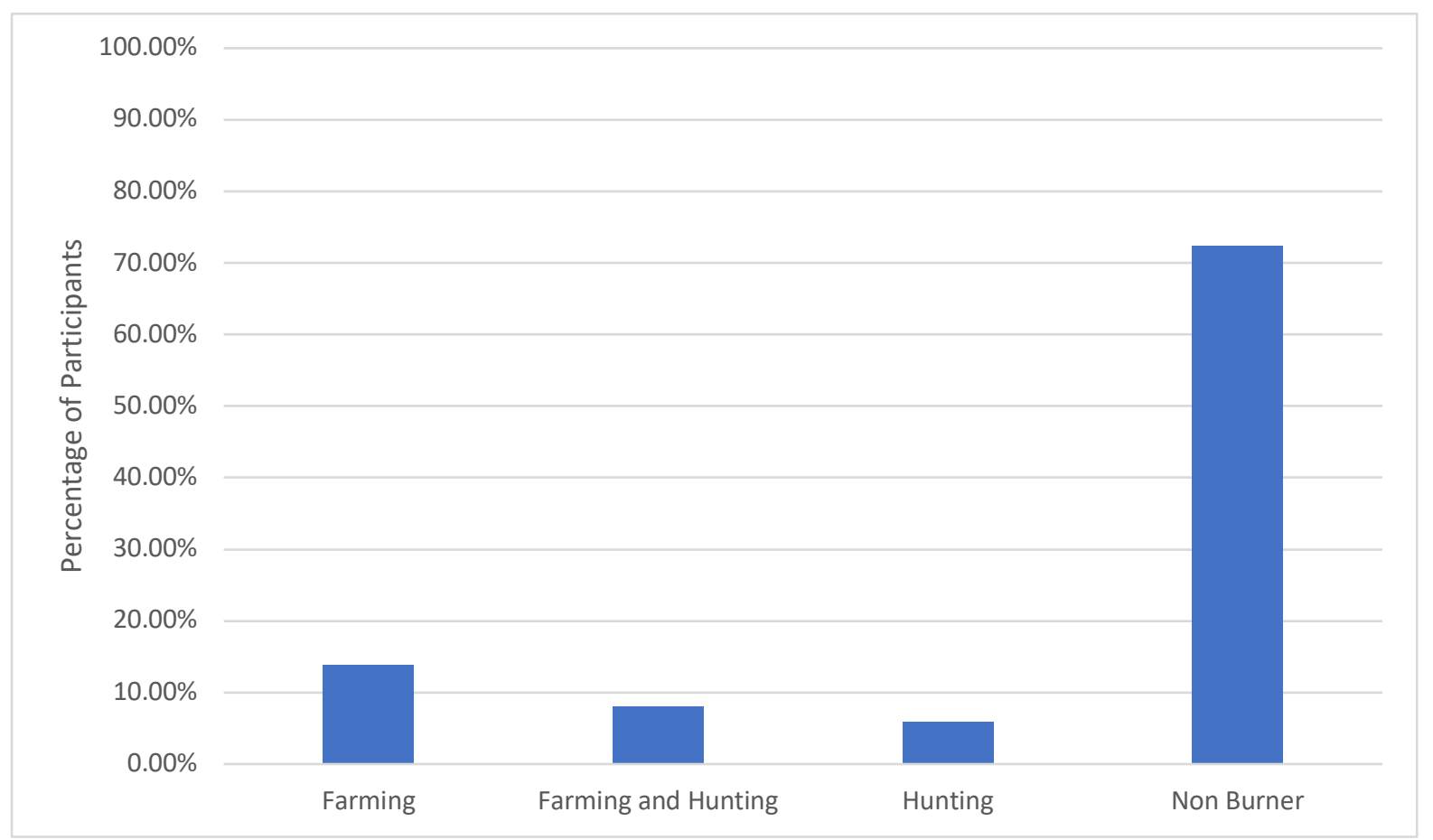

Fig 3 The overall percentage of participants from the 10 participating communities in the Northern Region, Ghana who used bush burning for farming, hunting, farming and hunting, or not at all. Participants were categorized into each category based on their responses to the screening question section of the barrier analysis survey conducted in 2019. Surveys $(\mathrm{n}=87)$ were conducted through an interview process with farmers in each community that volunteered to participate 


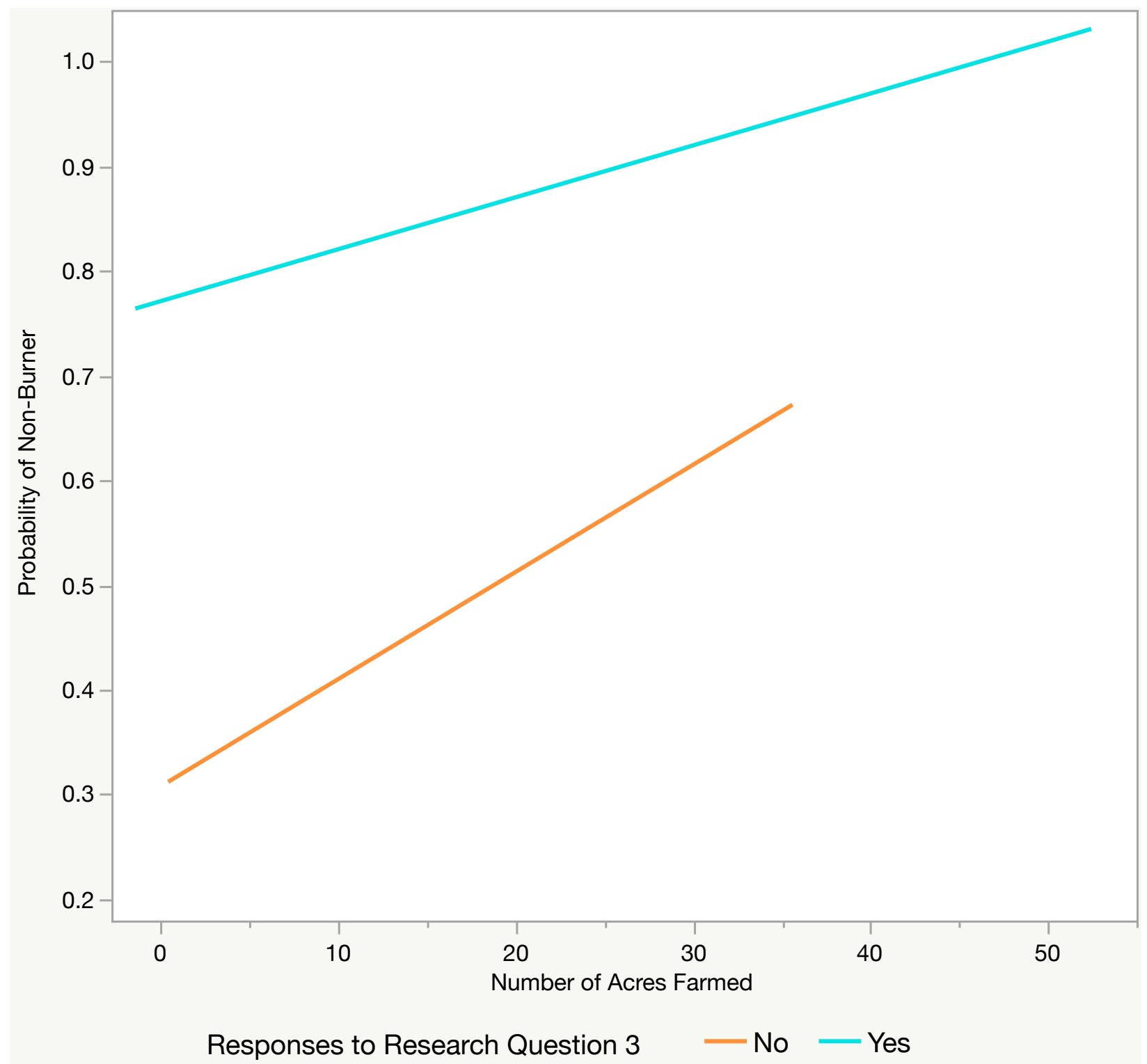

Fig 4 The probability of a participant, from one of the 10 participating communities in the Northern Region, Ghana, being categorized as a non-burner for farming. Probability was calculated using years of farming experience and whether a participant thought that bush burning had a negative effect on their farm from research question 3 . Surveys $(\mathrm{n}=87)$ were conducted in 2019 through an interview process with farmers in each community that volunteered to participate 


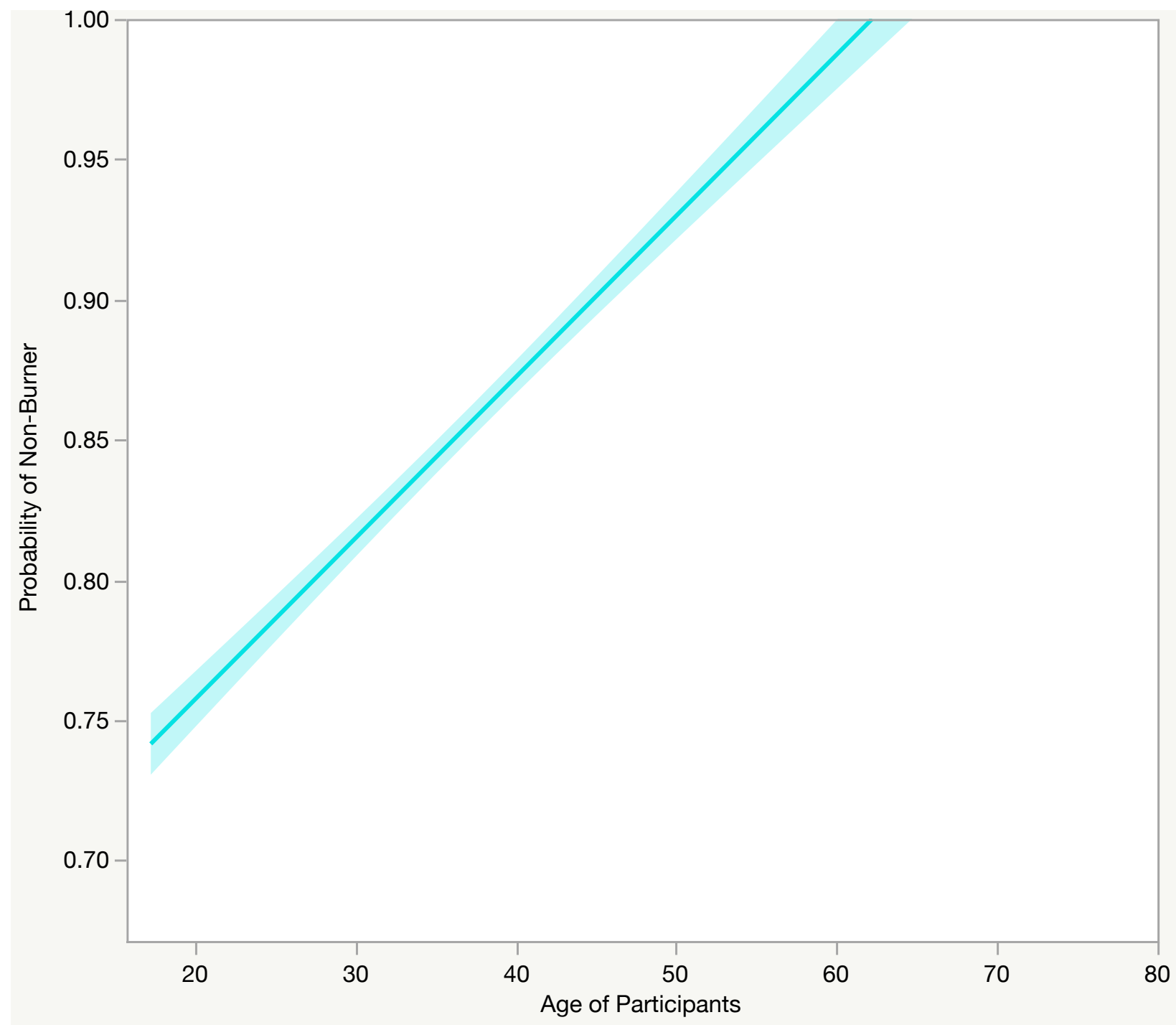

Fig 5 The probability of a participant, from one of the 10 participating communities in the Northern Region, Ghana, being categorized as a non-burner for hunting. Probability is calculated using age of the participants. Surveys $(n=$ 87) were conducted in 2019 through an interview process with farmers in each community that volunteered to participate 


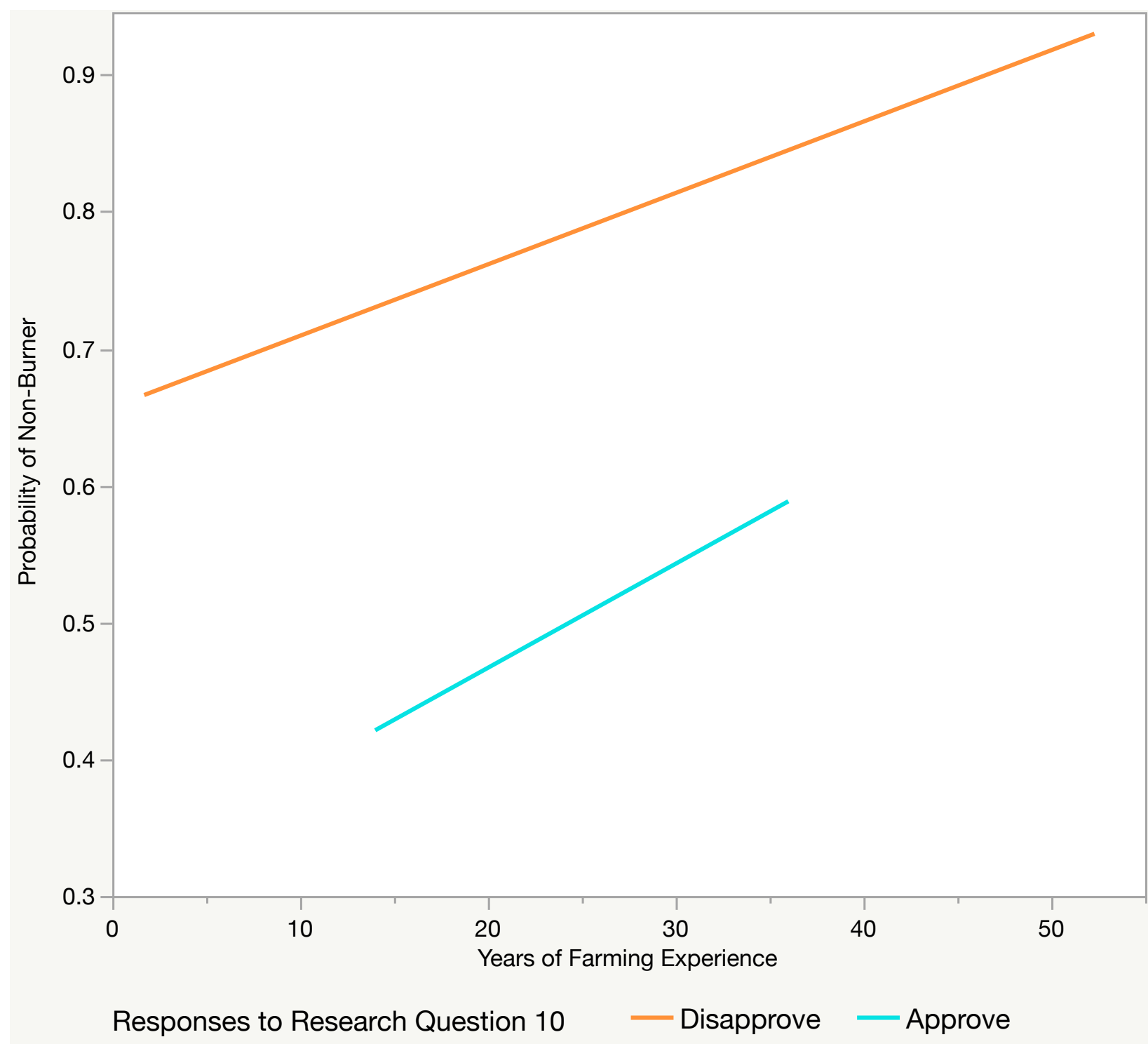

Fig 6 The probability of a participant, from one of the 10 participating communities in the Northern Region, Ghana, being categorized as a non-burner for either hunting or farming. Probability is calculated using years of farming experience and whether a participant thought that God approved or disapproved of bush burning from research question 10. Surveys $(n=87)$ were conducted in 2019 through an interview process with farmers in each community that volunteered to participate 


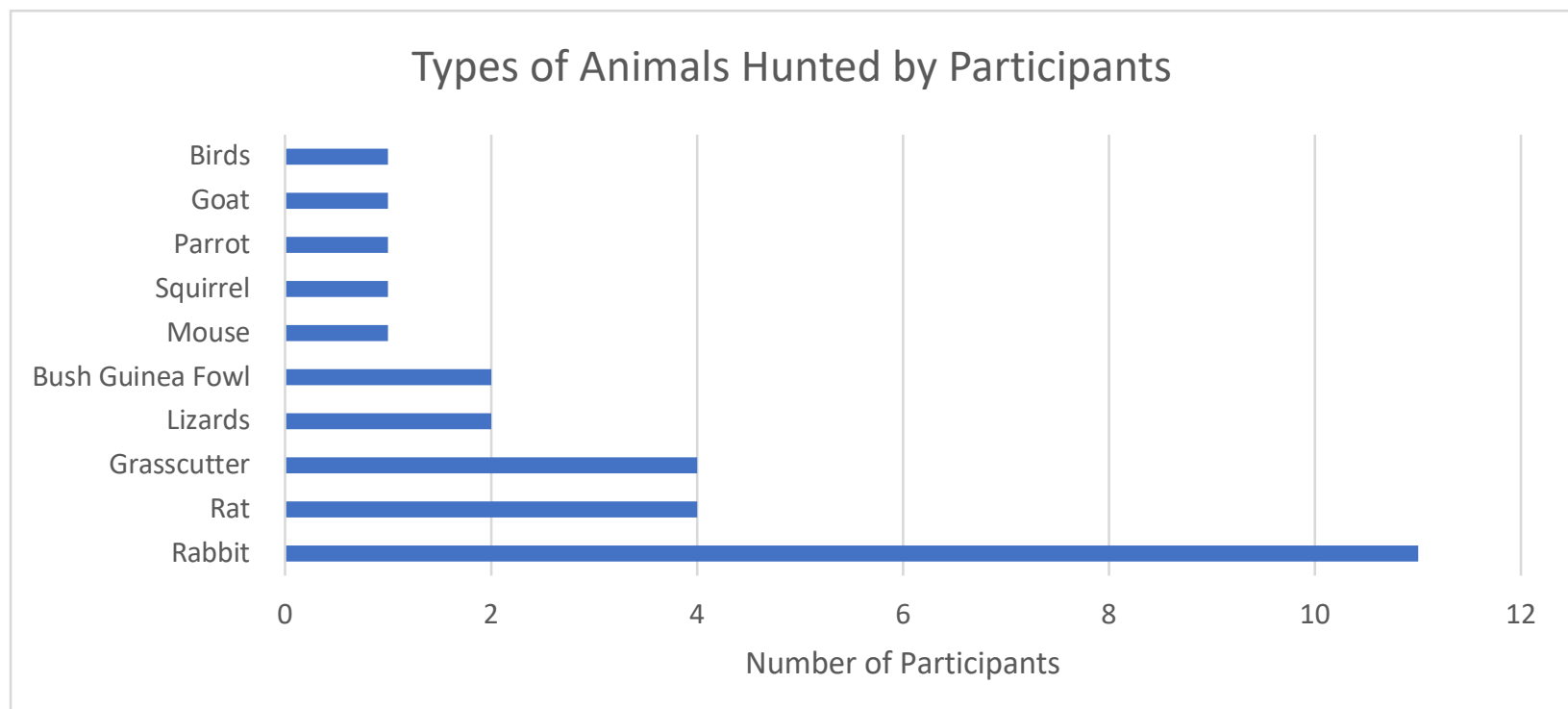

Fig 7 The number of participants and the species they hunted from the 10 communities in the Northern Region, Ghana that participated in the barrier analysis survey conducted in 2019. Surveys $(n=87)$ were conducted through an interview process with farmers in each community that volunteered to participate 
Appendix I: Barrier Analysis Survey- the questions asked each participant during the survey.

\author{
Barrier Analysis Survey \\ Bush Burning by Farmers
}

\title{
Demographic Information:
}

Survey and Recording No:

Date:

Participant's Name:

Translator's Name:

Sex:

Age:

Community:

No. of Acres Farmed:

Years of Farming Experience:

Doer/Non-Doer: 


\section{Screening Questions}

1. Have you ever practiced bush burning on your farm?
a. Yes
b. No
c. No Response

2. When was the last time you burned your fields? Have you noticed a change in your crop yield since you started bush burning?

3. Have you ever practiced bush burning to hunt?
a. Yes
b. No
c. No Response

4. What types of animals have you hunted in the past? Have you noticed a change in wildlife present for hunting? 


\section{Research Questions}

1. Perceived Severity: Compared to other agricultural practices how important do you think bush burning is in affecting your crop yield?

2. Perceived Severity: Compared to other hunting practices how serious do you think bush burning is in affecting the presence of various animals?

3. Perceived Risk: Do you think that bush burning has a negative effect on your farm/ crop yield?
a. Yes
b. No
c. No Response

4. Perceived Risk: Do you think that bush burning has a negative effect on the animals you are able to hunt?
a. Yes
b. No
c. No Response

5. Perceived Action Efficacy: Do you think that bush burning helps your farm/ crop yield?
a. Yes
b. No
c. Maybe
d. No Response

6. Perceived Action Efficacy: Do you think that bush burning helps you to hunt?
a. Yes
b. No
c. Maybe
d. No Response

7. Perceived Self- Efficacy/ Skills: With your current knowledge, skills, and resources, in your opinion are you able to properly care for your farm?
a. Yes
b. No
c. No Response 
8. Self-Efficacy/ Skills: What personal skills/ knowledge/ resources make it easy for you to practice (or not practice) bush burning?

9. Self- Efficacy/ Skills: What personal skills/ knowledge/ resources make it difficult for you to practice (or not practice) bush burning?

10. Perceived Divine Will: Do you think that God approves or disapproves of your bush burning?
a. Yes
b. No
c. No Response

11. Perceived Positive Consequences: What do you see as the advantages or benefits for bush burning?

12. Perceived Negative Consequences: What do you see as the disadvantages for bush burning?

13. Perceived Policy: Are there any community rules in place against bush burning?
a. Yes
b. No
c. No Response

14. Perceived Cultural Norms: Are there any cultural rules or taboos against bush burning?
a. Yes
b. No
c. No Response

15. Perceived Social Norms: Who approves of bush burning? Elders, Chief, Family Members, Religious Leaders?

16. Perceived Social Norms: Who disapproves of bush burning? Elders, Chief, Family Members, Religious Leaders?

17. Cues for Action/ reminders: How difficult is it for you to remember to practice, or not practice, bush burning?

18. How difficult is it for you to access tools and materials to practice, or not practice, bush burning?

19. Future Behavior Change: What actions, strategies, or interventions do you think would be effective to encourage farmers to not practice bush burning? 